\title{
Cell communications among Microorganisms, Plants, and Animals: Origin, Evolution and Interplays
}

\section{Yves COMBARNOUS* and Thi Mong Diep NGUYEN}

«Physiologie de la Reproduction \& des Comportements» Laboratory, Centre National de la Recherche Scientifique (CNRS), Institut National de la Recherche Agronomique \& Environnementale (INRAe), University of Tours, 37380 Nouzilly (France).

*Correspondence: yves.combarnous@inrae.fr ; Tel.: +33(0)247427650 (Y.C)

\begin{abstract}
Cells communicate with other cells not only within the same individual but also with cells in other individuals belonging to the same species or other species. These communications occur between two unicellular species or two multicellular species, or between unicellular and multicellular species. The molecular mechanisms involved exhibit diversity and specificity but they share common basic features which allow interferences between communications in different species.

Cellular communications play pivotal roles in all uni- and multi-cellular species, leading to an outstanding variety of essential biological processes not only within each species but also for numerous favorable interactions between uni- and multi-cellular species. These interactions have been made possible by the high degree of conservation of the basic mechanisms of many ligandreceptor pairs in evolutionary remote species. Moreover these inter-species communications have played an important role during Evolution and must have been positively selected, particularly when mutually beneficial. Synchronization, by chemical communications, of populations of protocells emerging from a syncitial root could have facilitated their emergence into living cell populations and explain their resemblance among microorganisms, plants and animals.
\end{abstract}

Keywords: hormone; quorum sensing; receptor; bacteria; fungi; metazoa; plants; microbiota; evolution;

\section{Introduction}

The cell is the structural and functional unit of all living organisms. Unicellular organisms such as bacteria, archeas, yeasts, or protists consist of a single cell. In contrast, multicellular organisms such as sponges, nematodes, trees, or vertebrates can comprise hundreds to billions or even trillions of cells. In such complex multicellular species, the cells exhibit a large number of differentiated phenotypes playing highly-specialized functions and are often associated within individualized organs. The cellular activities are coordinated at the level of each organ as well as between organs, to allow adaptation of the living organism as a whole, to its environment. This coordination rests on the traffic of information between all cell types and constitutes in animals the endocrine, nervous and immune systems.

In unicellular species, all cells seem identical and independent, suggesting that it is the survival and reproduction of each of them that ensures the sustainability of these species. Nevertheless, communications do indeed exist between these cells hence allowing some coordinated common 
responses as well as specialized roles for sub-populations. These coordinations optimize the development and survival of unicellular species populations.

Moreover, information exchanges are not limited to cells inside an organism, not even to cells belonging to one given species. They also exist between cells from different species, whatever unicellular, or multicellular.

Unicellular species have been prosperous for approximately 3.5 billion years. They can communicate indirectly through soluble mediators to regulate their growth and/or phenotype according to the available food resources. In spite of this success, multicellular species relying on direct cellular adhesiveness and specialization, also emerged several hundred million years ago. The main innovation in plants and metazoan, is the formation of highly specialized cell populations, requiring proper communications inside these organisms to ensure their development, survival, and reproduction.

All intercellular communications rely on intercellular messengers (mediators) and their cognate receptors in their target cells. The receptors play pivotal roles as they are at the connection between intercellular communications and downstream intracellular signaling. Despite the huge diversity of communications among living species, the number of receptor types and transducton mechanisms is rather limited, suggesting their conservation during the Evolution.

In the present paper, we draw a general picture of cell communications inside multicellular and unicellular species but also between different species, whatever unicellular and/or multicellular. This general view is aimed to show the discrete but outstanding place of endocrine communications inside the broad spectrum of all cellular communications.

\section{Origin and evolution of cell communications}

\subsection{Origin}

The origin of cell communications cannot be directly studied experimentally. Only a global view of current cell communications can guide us to speculate about their origin. To identify the oldest communication pathways between cells, the origin of the cells themselves, i.e. of Life on Earth, has to be considered.

It is highly challenging to trace back the unique history of Life, approximately 3.8 billion years ago [1]. A wide range of theoretical and experimental methods have been developed for constructing and testing possible evolutionary scenarios of prebiotic evolution, from the very beginning to the emergence of the first living cell(s) [2]. It is generally accepted that multicellular organisms emerged from unicellular organisms [3] and that communications became mandatory a long time after cell emergence. However, cyanobacteria, which are one of the earliest types of bacteria, dating back to between 3.4 and 2.8 billion years ago, formed huge colonies (stromatolites). It is thus likely that Life actually began much earlier, perhaps as early as 3.8 billion years ago, and most likely, under the form of synchronized cell populations.

Taking this into consideration, the protocells and first living cells must have never existed in a truly isolated state. Chemical communications might have already existed among protocells and were probably essential for the emergence of living cells. If true, this hypothesis implies that the first living cells were not isolated and emerged from inanimate protocell communities without rupture of communications between them. 
The hypothesis of synchronized protocell populations is difficult to prove (or disprove) but would make sense. For example, to avoid extinction by dilution, the protocells must out-compete other vesicles either by having a more rapid cycle, thereby generating more progeny during division or by surviving destructive processes more efficiently [4]. Synchronization of populations of protocells, requiring chemical communications, should have given them an advantage in terms of number and then facilitated their emergence into living cell populations. Also, these first cell populations, retaining chemical communications, would have offered a more protective and stable milieu for the emergence of Life. The emergence of prokaryote as well as eukaryote cells from a communal syncitial root [5] is interesting in this respect.

The fact that living cells are non-equilibrium systems suggests that life can emerge only from nonequilibrium chemical systems, thus needing energy input. The energy from the sun is the ultimate source of energy for sustaining life on earth. From an astrobiological standpoint, non-equilibrium chemical systems can arise naturally when solar irradiation strikes rotating surfaces of planets [6]. It is tempting to imagine that solar photoperiodism might have synchronized protocells chemical functioning, and then kept synchronizing biological metabolism and divisions in the newly-formed cell populations. Their synchronization should have favored the functional cohesion between cells through circadian light exposure. Interestingly, cell communications are still synchronized by light, circadian rhythms in a vast number of prokaryote, plant, and animal species.

\subsection{Evolution}

Intercellular mediators emerged during Evolution in conjunction with the appearance of their cognate receptors. In some cases, one of them (ligand or receptor) appeared first and "found" its counterpart later, but, more often, they appeared "simultaneously" at the phylogenetic time scale [7]. Probably, molecules with no partner (i.e., with no role) are not conserved for long in the following generations. When ligand or receptor appeared a long time before its current partner, it is likely that it had another interacting partner (i.e., another role) in the meantime.

The most-ancient intercellular messengers probably were intracellular metabolites like ATP and other nucleotides, released by damaged cells. In receiving cells, their initial targets probably were the same proteins as those recognizing the internal molecule. To discriminate the outcoming messenger molecules from their own intracellular ligands, part of these intracellular proteins must have evolved to become located at the surface of the cells. The plasma membrane is a particularly favorable place for such receptors to discriminate outside messengers from their own metabolites. De novo protein domains emerging from non-coding thymine-rich DNA sequences must have played advantageous roles in this evolutive process. Indeed such DNA sequences exhibit a high potential to be translated into transmembrane domains [8] and these domains next to the coding sequences of copies of the intracellular protein can have led to this new location at the plasma membrane. Since these cells belong to the same species, this initial phenomenom corresponded to an autocrine mechanism. From this simple autocrine communication, diversification of cell phenotypes can have led to more and more complex and specific communication networks in microorganisms, plants and animals. In prokaryot and eukaryot microorganisms, quorum sensing represent the most genaral example of intercellular communications. In plants, specialized molecules play specific roles in communications 
between their various parts for coordinating their development and functions. In animals, an even higher integration occurs through their endocrine, neuronal and immune systems.

Many hormones are released in a pulsatile manner under neuro-hormonal control, and the frequency of their pulsatile secretion governs the efficacy of their signaling. For example, in vertebrates GnRH under Kisspeptin stimulation exhibits pulsatile secretion [9] that is important for the balance of pituitary FSH and LH secretions and consequently for correct gametogenesis [10]. It is, therefore, essential to consider the identity of intercellular mediators but also their concentrations and eventual pulsatilities in the analysis of intercellular communications.

\subsection{Mediators and receptors}

The mediators involved in cell-cell communications are very diverse in size, from MW 30 for NO to MW $>450000$ for adiponectin. They are also very diverse in term of water solubility and volatility. Most of them are soluble in water, but some are not like cell surface proteins or extracellular matrix as well as hydrophobic mediators that must be transported by proteins to reach their targets in aqueous media. Many are volatile in air and reach their target receptors over very long distances (pheromones).

The receptors are diverse in term of specificity to match the mediators diversity but the number of receptor types is not very high as shown in table 1 , and their general downstream signaling pathways are also in limited number (figure 1).

\section{Cell communications and communitarianism in unicellular species}

By definition, the unicellular species do not possess specialized differentiated organs and cells. Nevertheless, communications exist between cells of unicellulars, inside or between different species. The membrane receptors in bacteria often directly respond to nutrients [11], or to Quorum Sensing (QS) signaling molecules [12], and those in yeasts can besides respond to pheromones [13].

\subsection{Bacteria}

\subsubsection{Biofilms}

Some bacteria communities develop in synchronized fashion and form biofilms. In these protective films, bacteria construct a niche in which they share labor: Exterior cells fend off threats, while interior cells absorb nutrients for the whole community. These biofilms, consisting of polysaccharides, proteins, surfactant agents, lipids, glycolipids, etc., allow the bacteria to settle on biological surfaces (mucous membranes, teeth, etc.) or non-biological surfaces (pipes, floors, etc.) [14]. Biofilms protect the whole community of bacteria against antibiotics, disinfectants, or the host's immune response. Bacteria possess different mechanisms to recognize fibronectin and other proteins that are present in host-cell membranes to form adherent biofilms. They also rely on extracellular DNA (eDNA), that is present in the biofilm matrix, facilitates the initial stage of adhesion to biomaterials, forms a structural backbone, and acts as an aggregating glue $[15,16]$. It is still unclear, however, whether eDNA 
functions as a signal that promotes biofilm formation or solely as an early component of biofilms, mediating cell adhesion to surfaces and other cells.

\subsubsection{Quorum sensing}

The establishment of a biofilm requires a sufficient number of bacteria, and specific messenger molecules inform populations of bacteria that the required quorum is reached. A variety of quorum sensing (QS) signaling molecules and cognate receptors exist in various bacteria [17].

Both Gram-positive and Gram-negative bacteria use quorum sensing systems with mediators named autoinducers (AI) [18]. Four main general types of autoinducers have been described.

AI-1 mainly present in Gram-negative bacteria, are $\mathrm{N}$-acylated homoserine-lactones (AHL) with a core AHL ring and a 4-18 carbon acyl chain that can contain modifications [19]. They bind to specific LuxR-type cytoplasmic receptors [20] which control transcription of numerous virulence genes, and to LuxN-type membrane receptors. AI-2, present in both Gram-positive and Gram-negative bacteria is are furanosyl borate diesters, considered as universal signal involved in unicellular interspecies communications [21,22]. AI-2 has either a positive or negative effect on biofilm formation in different bacteria. AI-3 mainly in Gram-positive systems typically use secreted oligopeptides [23,24] and twocomponent systems (TCS), which consist of membrane-bound sensor kinase receptors (QseC) and cytoplasmic transcription factors (QseB) which direct alterations in gene expression [12,25]. The QseC receptor responds to AI-3 but also to AI-2 and, additionally, to epinephrine/ norepinephrine from eukaryotic hosts. Hence, it mediates both intra- and inter-species (even inter-kingdom) signalings $[26,27]$.

P. aeruginosa also makes use of another QS system named Pseudomonas Quinolone Signal (PQS) [28] in which 2-heptyl-3-hydroxy-4(1H)-quinolone binds to its specific LysR-type transcriptional regulator receptor (PqsR) to control the synthesis of a rhamnolipid, which is a critical surfactant for biofilm formation [29].

Because QS systems are very efficient in bacterial virulence and resistance, they have become targets for host defense. For example, the human immune cells destroy the QS messenger AHL via a class of quenching enzymes named paraoxonases. The inhibition of cooperativity in pathogenic bacteria, is thus essential for the host's survival.

Interestingly, communities of the bacteria Bacilus subtilis belonging to nearby separate biofilms can coordinate their growth in phase opposition oscillations. Such an alternate growth allows them to take advantage, each at its turn, of the total available resources during their alternating growth phases.

\subsubsection{Electrical signals}

The potassium signals released in biofilms can travel with constant strength for more than 1000 times the width of a typical bacterial cell. This electrical communication is considerably quicker and more extensive than quorum sensing. Bacteria, like neurons, pump ions across their membranes, and several recent papers have reported spikes of electrical activity in bacteria, which suggest that, like 
neurons, bacteria use potassium ions to propagate electrical signals [30]. Besides, Bacillus bacteria seem to use potassium ions to recruit free-swimming cells to the community. Interestingly, the bacteria attracted not only other Bacillus but also unrelated species, to form multi-species communities.

\subsubsection{Viruses and virus-related entities}

Viruses and other capsidless replicons such as plasmids, transposons, and viroids promote an enormous amount of exchanges among bacteria. Bacteriophages are present everywhere bacteria are located and kill a lot of them but, never all of them, without the risk of disappearing themselves. In a way, bacteriophages are kind of QS mediators allowing bacteria to sense how many of them have already succumbed. Symmetrically, bacteriophages take advantage of the bacterial QS pathways to swap from active lytic to dormant lysogenic states. This coordination of the lysis-lysogeny decision of phages in Bacillus is based on the release of phage-specific communication hexapeptides. These peptides are imported in bacteria by oligopeptide permease transporter (OPP) and bind to their intracellular receptors which then no longer activate the expression of an inhibitor of lysogeny and consequently favor lysogeny [31-33]. This system also represents a communication system between viruses of different generations since the late newcomers infecting a population of bacteria are oriented to lysogeny. Doing so, they wait until the bacteria around are much less infected, to resume their lysis phase, and thus have access to naïve bacteria to replicate exponentially. Symmetrically, this mechanism offers bacteria a means to stop its exponential lysis by taking control of virus replication. Large parts of animal genomes, including human, consist of integrated virus sequences indicating that this mechanism has been widespread during Evolution.

Besides, by transporting bits of bacterial DNA or RNA, bacteriophages and other virus-related entities bring genetic information from one bacteria to the other through horizontal gene transfer which is favored by the high density inside biofilms. Viruses might thus, also constitute a communication channel as well as an evolutionary pathway for bacteria.

\subsection{Yeasts and fungi}

Yeasts and fungi are different forms of the same eukaryote species. Yeasts are the unicellular forms, whereas fungi form multicellular branching filaments called hyphae. In many species, the two types exist depending on environmental conditions. In others, they live only under one form but can be recognized as related thanks to their biochemical or genetic characters. Yeasts, in particular, Saccharomyces, have been extensively studied because of their food-processing interest or their pathogenicity.

Direct communications between yeasts occur through membrane proteins such as flocculins, which are lectins recognizing their partners' polysaccharide chains to form a solid mass (veil, biofilm, etc.) [34,35]. Yeasts also communicate via soluble molecules that can diffuse and affect the community's organization on a long-range (quorum sensing). QS molecules identified in fungi include peptide pheromones, oxylipins, aromatic alcohols (such as tyrosol and farnesol [36]), $\alpha 1-3$ glucans [37] and pantothenic acid [38]. For example, C. Albicans cells develop as budding yeasts when inoculated at $\geq 10^{6}$ cells per $\mathrm{ml}$ and as mycelia when inoculated at $<10^{6}$ cells per $\mathrm{ml}$. For this transition, tyrosol and farnesol act through transcription factor-receptors as QS molecules, which respectively, accelerate 
and block the change from yeasts to hyphae morphology [34]. Moreover, farnesol inhibits the immune system of humans hosting C. Albicans' [39].

Communications inside fungi mycelia pass through pores in the septa delimiting the individual cells [40]. There are also communications between mycelia from the same species and, possibly, from different species as well as between mycelia and plants and/or bacteria [37,40-45].

\subsection{Large unicellular eukaryotic microorganisms ("protists")}

Amoebas, paramecia or trypanosomes are unicellular organisms with complex and large-sized morphologies. These cells present, however, in case of limited resources, phases with several different phenotypes.

In the amoeba, D. discoideum cyclic AMP acts as an intercellular mediator. Its export co-occurs with its intracellular synthesis by adenylate cyclase. Adenylate cyclases contain a general structure similar to ATP Binding Cassette $(\mathrm{ABC})$ transporters [46], which are known to export anionic cargoes like cAMP in other organisms. ABC transporter inhibitors disrupt amoeba development in a manner consistent with a lack of cAMP export, indicating that cAMP plays an intercellular messenger role during $D$. discoideum development. In fact, cAMP is released in a pulsatile manner, and its frequency of release is essential, as there is an optimal pattern of periodic stimulation that maximizes target cell responsiveness [47].

When the density of bacterial prey becomes low compared to the amoeba population, the sensor protein PSF concentration decreases, leading to activation of protein kinase YakA which relieves the inhibition of expression of a cAMP-dependent protein kinase. The latter stimulates the expression of several genes, including a cAMP membrane receptor responsible for the aggregation in spores. Such a positive activation loop favors spore formation by cAMP $[47,48]$.

Amoebas also use quorum sensing-like communication systems initially based on the complex dipeptide glorin [49], to coordinate the periodic transition from uni- to multicellularity.

Among trypanosomes, the cross-species interactions between QS systems have important implications for their virulence, transmission, competition and evolution [50] and might be exploited to combat the pathogenic species.

\subsection{Lichens}

Lichens are long-term intimate symbiotic partnerships between mushrooms and photosynthetic algaes occupying nutrient-poor niches [51]. Inter-species communications are thus crucial for the initial steps of symbiosis in lichen formation and development [52]. Recognition of compatible algal cells is performed by specific lectins produced and secreted by the potential mycobiont. For example, the lectin of Peltigera canina recruits both algal cells (chlorobionts) and cyanobacteria (cyanobionts such as Nostoc), forming high-affinity bonds with different galactose units in the poly- $\alpha-1,4-$ galactoside side chain of their wall. Free non-motile cells of the cyanobacterium that bind the lectin are recruited and move toward the lectin source $[53,54]$. Upon reaching the maximal concentration 
of the gradient, the cells become desensitized, and lectin binding promotes cell aggregation between the two partners [55].

Bacterial communities (particularly cyanobacteria) also participate in the constitution of these interspecies associations [56]. Some of these bacteria possess the genes allowing the synthesis of auxins and can thus attract their eukaryote partners (mushrooms and/or algaes), or be accepted by them.

\subsection{Communities of extremophile species}

Different species form stable associations to withstand harsh conditions Extremophiles, live at temperatures up to $120^{\circ} \mathrm{C}$ and depths more than $3 \mathrm{~km} \mathrm{[57]} \mathrm{as} \mathrm{they} \mathrm{survived} \mathrm{the} \mathrm{late} \mathrm{heavy} \mathrm{meteorite}$ bombardments by colonizing deep habitats [58]. The conditions considered as "extreme" today (hot or cold, harsh atmosphere, etc.) were "normal" during many periods since four billion years ago.

During Earth history, there were several periods of high or low-temperature conditions that must have impacted life and also periods during which the climate has been impacted by Life (atmospheric $\mathrm{O} 2$ increase, for example). Almost complete glaciations of the planet occurred between -2400 and -2100 MY and again between -720 and -660 MY before present (the snowball earth). Even today, there is a large number of microbes known to inhabit very harsh environments on our planet, including permafrost, hot springs, deep ocean hydrothermal vents, toxic sludge of polluted areas, and acidic lakes.

It is difficult to know whether real communications exist between these associated extremophile species or whether there is only a mutualization in the use of available resources of their harsh environment. New data suggest that environmental sensing and responses in natural multi-species microbial communities could arise through noncoding RNA-mediated gene regulation [59].

\section{Cell communications in multicellular species}

Multicellularity has only emerged and succeeded in fungi, algae, plants, and animals [60]. All multicellular organisms are eukaryotes and the nuclear chromatin structure in each cell controls its specific fate through the expression of homeotic genes. This development in animals is controlled and coordinated only by a few extracellular ligands (such as Hh, Wnt, FGF, BMP and some others) providing complex structuring information via their identities, concentrations, combinations and dynamics [61]. Intercellular communications through soluble mediators already existed in unicellular organisms, probably since 3.5 billion years ago. The specialization of various cell populations in multicellular species emerged much more recently, approximately 600 million years ago [62]. In these species, both direct and indirect cellular communication mechanisms co-exist.

\subsection{Main cell communication pathways}

Intercellular communications in multicellular organisms arise via four different molecular mechanisms: 1 / cytoplasmic bridges, 2 / exosomes, and ectosomes, 3 / interactions between membrane proteins of adjacent cells, and 4/ messenger molecules (mediators) controlling more or less distant target cells. 
In animals, adjacent cells can be functionally connected by direct contacts of their plasma membrane external surfaces. In plants, the separation of cells is evident in the microscope, as they possess outer skeleton-forming walls. Nevertheless, they are not functionally isolated from each other and communicate in various ways.

\subsubsection{Bridges between contiguous cells}

There are several types of cytoplasmic bridges, including gap junctions [63,64], plasmodesmata [65], tunneling nanotubes [66], and others formed by incomplete cytokinesis [67].

Gap junctions are pores formed by connexons allowing the passive passage in an aqueous environment of small-sized molecules $(<1.5 \mathrm{kDa})$.

Plasmodesmata found only in plants, are membranous channels that link the cytoplasm, plasma membranes, and endoplasmic reticulum of adjacent cells to provide cytoplasmic and membrane continuity for molecular trafficking $[68,69]$. They are wide enough to allow the passage, not only of cytoplasmic hydrosoluble molecules but also of their endoplasmic reticulums forming a desmotube. Tunneling nanotubes (TNT), also named filopodia [70], mediate cytoplasmic molecular trade among neighboring or distant $(\sim 500 \mu \mathrm{m})$ cells of the same or different species, thus facilitating both antagonistic and cooperative interspecies interactions [71]. Thin TNTs $(<0.7 \mu \mathrm{m}$ in diameter) contain only F-actin, whereas thick ones $(>0.7 \mu \mathrm{m})$ contain microtubules in addition to F-actin [72]. Lysosomes, mitochondria, but also bacteria, viruses, or prion, can travel via thick TNT, while the most studied function of thin TNT is the propagation of calcium flux [70].

Cytoplasmic bridges due to incomplete cytokinesis are found in animals: in male [69,73] and female gametes [74,75], and various other cell types (osteoclasts, hepatocytes). Such bridges are also found in plants [76].

Syncytia are kind of extreme forms of cytoplasmic bridges leading to multinucleate cells [77] as in muscle [78] or placenta $[79,80]$ in animals, and that is more common in fungi in which cell cytoplasms communicate through large pores in their septa [81,82].

\subsubsection{Extracellular vesicles : exosomes and ectosomes}

Cells can exchange cytoplasmic material even when they are not in direct contact. Indeed, exosomes and ectosomes, are two distinct kinds of extracellular vesicles (EV) generated by all types of cells. They play critical roles in intercellular communication. These EVs $(50-150 \mathrm{~nm}$ for exosomes and 100-500 nm for ectosomes) differ in their mechanisms of assembly, composition, and regulation of release [83]. The tip of primary cilia is among the EVs shedding sites [84]. The EVs navigate through extracellular fluid before undergoing fusion with their target cells leading to the discharge of their cargoes, including proteins, lipids, and nucleic acids, into the target cells cytoplasm to affect the activity of transcription factors, signaling proteins and many enzymes [83].

EVs have been recently described in plants where they contribute to innate immune defense and communications with rhizobial and nodule microorganisms $[85,86]$. They are thus present in all domains of Life [87] and their roles should be taken in consideration with higher attention. 


\subsubsection{Direct interactions between membrane proteins}

Many membrane multidomain proteins [88] allow cell-cell adhesiveness and communications. Many of these proteins exhibit repeated stable conformations such as Leucine-Rich Repeats (LRR) folds [89] fibronectin-like folds [90,91], immunoglobulin-like folds [92,93] or EGF-like repeats [94,95].

In animals, cells are in contact with each other not only directly through these adhesion proteins but also indirectly via a kind of extracellular "glue" the extracellular matrix, ECM, which includes proteins such as collagens, fibronectins or laminins [96-98]. Various adhesion proteins such as cadherins, integrins, CAM (Cell Adhesion Molecules), selectins, etc., participate in these direct or indirect contacts between cell surfaces [99-101]. A particular intercellular connection is the synapse either between neurons or between a neuron and a muscle cell [102].

Specific animal cells are mobile (gametes, blood cells, etc.) and enter specifically in touch with various other cells of the organism, so modulating each other's activity. In plants, there is a thick polysaccharide wall around most cells, which prevents the plasma membranes of neighboring cells from coming into contact. Besides, walls are stuck in the extracellular matrix made of pectin, which immobilizes plant cells, including germ cells that need a particular structure, the pollen tube, to come in contact [103].

Communications between proximate cells also exist through their common extracellular matrix (ECM) components among which aminosugars play a pivotal role in expressing a Glycomic Code [104].

\subsubsection{Remote intercellular mediators}

Almost all cells, in uni- and multicellular organisms, produce soluble messenger molecules (mediators), capable of influencing distant cells. In animals, the best-known soluble messenger molecules (mediators) are hormones, but they also include neuromediators, cytokines, growth factors, morphogens, etc.. Their target cells can be located at the contact of the mediator-emitting cell (post-synaptic cells) or, at a considerable distance in another individual (target cells for pheromones). In plants, many different hormones also exist, and they act at a very short distance, such as ethylene, or a more considerable distance such as auxin, gibberellins, and various phyto-œstrogens.

The mediators' receptors are located at the functional interface between intercellular communications and intracellular signaling. They belong to two prominent families: $1 /$ membrane receptors with their binding site at the external surface of cells, and 2/ intracellular receptors acting at the level of DNA (nuclear receptors in eukaryotes). The receptors of the first group bind to mediators that do not penetrate the cell, whereas those of the second group perceive only ligands capable of penetrating the cells.

As indicated above, DAMPs among which ATP play intercellular roles (alert, inflammation, regeneration) [105-107]. Other nucleotides (ADP, AMP, cAMP) and NAD (Nicotine Adenine Dinucleotide) and their metabolite, the nucleoside Adenosine, also have messenger roles in prokaryotes as well as in eukaryotes. These molecules, initially released in the extracellular space as a result of cell lysis, were subsequently released during evolution, under controlled conditions, and became specific intercellular messengers in most species. Themselves and many of their metabolites, now also play primary roles as intracellular messengers (ATP > cyclic AMP; NAD > ADPR, cyclic 
ADPR, NAADP). Similarly, ATP and NAD have retained intercellular messenger functions in animals in which they are ligands of the P2X receptor (ATP-gated receptor channel) and of the P2Y receptor (seven-transmembrane spanning receptor) that are both involved in pain sensitivity [108,109]. In contrast, adenosine acts through P1 receptors [110]. In plants, ATP [111], NAD+ [112] and some of their derivatives also play extracellular mediator roles.

Other molecules with intracellular roles have also gained intercellular mediator functions like some amino acids, such as glycine and glutamic acid, which act as neuromediators [113]. Furthermore, melatonin, which initially had only an intracellular antioxidant role, subsequently acquired a hormonal function through 7TMRs in metazoans [114].

Other intercellular mediators are either, small, simple molecules, such as nitrogen oxide (NO), amino acid derivatives (serotonin, melatonin, auxin, thyroxine, etc.), or amino acid polymers (peptide, protein and glycoprotein hormones, cytokines, growth factors, etc.), lipid derivatives (steroid hormones, prostaglandins, jasmonate, etc.) and various other molecules such as ethylene, gibberellins, etc.

\subsubsection{Receptors}

The receptors in plants and animals are either soluble intracellular transcription factors or proteins inserted in the plasma membrane (table 1.). The nuclear receptors exist both in animals and plants but whereas they form a large family of related transcription factors in animals [115], in plants diverse proteins serve as intermediaries in the genomic actions of the hormones [116]. These binding proteins in plants are structurally very diverse, in contrast to the kinship of animals' nuclear receptors. Nevertheless, the general mechanisms in animals and plants appear to share many similarities [117].

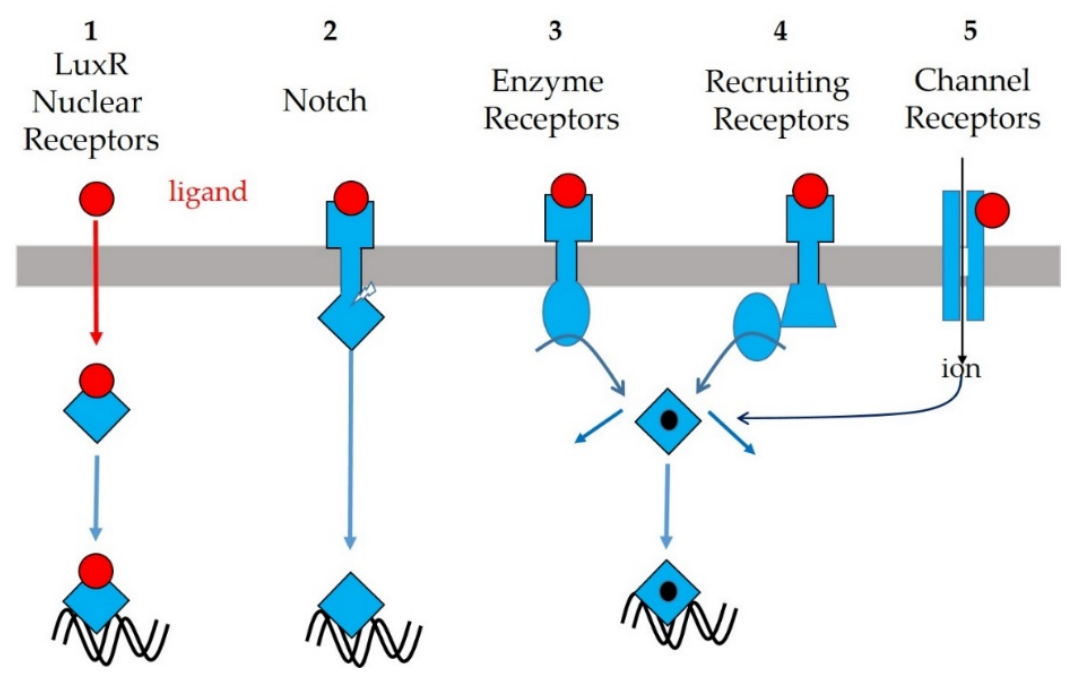

Figure1. General view of intercellular messengers' receptors and their downstream signaling pathways.

1. intracellular ligand-regulated transcription factor. 2-5 Plasma membrane receptors: 2. Protease-cleavable receptor with intracellular domain exhibiting trancriptional activity 3. Enzyme receptors (Tyr, Ser/Thr, His kinases, GMPcyclase, phosphatase); 4. Non-enzymatic receptors recruiting cytoplasmic partners (kinases, G proteins, scaffolding proteins); 5. Channel receptors (ionotropic). For details, see also table 1. 
In brief, as shown in figure 1, the plasma membrane receptors of animals, and plants are either: channel-receptors letting in specific ions [118,119]; receptors acting by direct catalysis (receptors with intrinsic enzymatic activity, i.e. protein kinase activity [120,121], or phosphatase activity [122], or guanylate cyclase activity [123,124]; receptors acting through recruitment of various downstream intracellular effectors (G proteins [125-132], adenylate cyclases [133-135], phospholipases C [136-138], soluble protein kinases [139-144], methyltransferases [145], proteases [146-149] etc.). These receptors possess a/ a very short or very large extracellular domain (ECD), b/ one, or several membranespanning sequences (seven in GPCR), and c/ an intracellular domain (ICD) comprising one or several peptide sequences. The ECD permits ligand binding whereas the ICD either possesses enzymatic activity like the insulin receptor (tyr-kinase) or TGF $\beta$ receptor (ser/thr kinase) (fig1.3), or recruits cytoplasmic soluble enzyme(s) like the growth hormone and cytokine receptors (Jak and Tyk kinases, or recruits G-proteins, like the numerous GPCRs (fig1.4) or it is clipped off as a transcription factor to perform intracellular signaling like the Notch receptor (fig1.2). Membrane receptors and downstream partners are generally concentrated at the level of lipid rafts [150] or primary cilium in metazoan [84,151]. The downstream signaling pathways and their evolution have been thoroughly described in a recent comprehensive review [152]

Many hormones are released in a pulsatile manner, and the frequency of their pulsatile secretion often governs the efficacy of their signaling. For example, GnRH under Kisspeptin stimulation exhibits pulsatile secretion [9] that is important for the balance of pituitary FSH and LH secretions [10]. It is, therefore, essential to consider the identity of intercellular mediators but also their concentrations and eventual pulsatilities in the analysis of intercellular communications.

In the most "primitive" metazoa, the distinction between neuronal, endocrine and immune systems is not obvious. For example, in cnidarians (medusae, corals), there is no endocrine gland, but the diffuse neurons secrete neuromediators and molecules that are chemicaly related to vertebrate hormones such as steroids, melatonin or GnRH [153]. During the Evolution, the endocrine system has gained in complexity in all invertebrates but even more in vertebrates due to the dual duplication of entire genome at the root of vertebrates' radiation, and to the emergence of the pituitary as an integrator of an important part of endocrine functions [154-156]. 
Yves Combarnous and Thi Mong Diep Nguyen (2020)

Table 1: Intracellular and membrane receptor families in microorganisms, plants and animals

\begin{tabular}{|c|c|c|c|c|}
\hline \multicolumn{2}{|c|}{ Receptors } & Mechanisms & Ligands & \\
\hline \multirow{6}{*}{$\begin{array}{l}\text { Intracellular } \\
\text { Ligand-regulated } \\
\text { Transcription } \\
\text { Factors }\end{array}$} & LuxR (LasR, TraR) & Transcription & QS autoinducers (various AHL) & Bacteria \\
\hline & LysR (PqsR) & Transcription & PQS (various Quinolones) & Bacteria \\
\hline & \multirow{4}{*}{ Nuclear Receptors } & Transcription & oleate ergosterol & Fungi \\
\hline & & Transcription & Florigen (PEBP) & Plants \\
\hline & & Transcription & $\begin{array}{c}\text { brassinosteroids, gibberellins, jasmonates, } \\
\text { salicylates... }\end{array}$ & Plants \\
\hline & & Transcription & $\begin{array}{c}\text { Steroid \& thyroid hormones, VitD, RA, } \\
\text { prostaglandins ... }\end{array}$ & Animals \\
\hline \multirow{4}{*}{$\begin{array}{c}\text { Other } \\
\text { Intracellular } \\
\begin{array}{c}\text { Ligand-regulated } \\
\text { targets }\end{array}\end{array}$} & Ubiquitin-ligase & protein degradation & auxin & Plants \\
\hline & Monomeric $G$ protein (Ste2-3p) & $?$ & farnesol tyrosol tryptophol & Fungi \\
\hline & NO sensing protein & Two-step His/Asp transfer & Nitric Oxide & Bacteria \\
\hline & soluble guanylate cyclase & cGMP increase & Nitric Oxide & Animals \\
\hline \multirow{8}{*}{$\frac{\text { Plasma Membrane }}{\text { Enzyme-Receptors }}$} & His kinases & Two-step His/Asp transfer & $\begin{array}{c}\text { Environment signals } \\
\text { (osmol, chemicals., temp, microorg) }\end{array}$ & $\begin{array}{c}\text { Bacteria } \\
\text { Archea }\end{array}$ \\
\hline & His kinases & Two-step His/Asp transfer & Ethylene, brassinosteroids... & Plants \\
\hline & His kinases & Two-step His/Asp transfer & arabinose, $\mathrm{Mg}^{++}$ & Fungi \\
\hline & Di-guanylate cyclase & di-cGMP increase & environment signals & Bacteria \\
\hline & Tyr kinases (RTK) & IRS, Shc Tyr phosphorylation & IGF, insulin, EGF... & Animals \\
\hline & Ser/Thr kinases & SMAD S/T phosphorylation & TGF $\beta$, BMP, Activin, Inhibin... & Animals \\
\hline & guanylate-cyclase & cGMP increase & ANF & Animals \\
\hline & Tyr-phosphatase & Tyr dephosphorylation & Proteoglycans or unknowns & Animals \\
\hline \multirow{10}{*}{$\frac{\text { Plasma Membrane }}{\begin{array}{c}\text { Non-enzyme } \\
\text { Receptors }\end{array}}$} & ionotropic R & Ion entry & $\begin{array}{l}\text { glutamate acetylcholine ... } \\
\text { amino acids ? } \\
\text { mechano-stress, sterols }\end{array}$ & $\begin{array}{c}\text { Animals } \\
\text { Plants } \\
\text { Bacteria }\end{array}$ \\
\hline & Notch & $\begin{array}{c}\text { Transcription domain liberation by } \\
\text { proteolysis }\end{array}$ & $\begin{array}{l}\text { Cell membranes proteins } \\
\text { (Delta Jagged Serrate) }\end{array}$ & Animals \\
\hline & Cytokine R & Kinase recruitment (JAK) & GH, Prl, interleukins, & Animals \\
\hline & $\mathrm{BcR}, \mathrm{TcR}, \mathrm{FcR}$ & Kinase recruitment (lck, lyn) & MHC, antigens, immunoglobulins & Animals \\
\hline & TNFR & $\begin{array}{l}\text { TRADD TRAF RIP caspases } \\
\text { recruitment }\end{array}$ & TNF & Animals \\
\hline & Integrins & $\begin{array}{c}\text { SFK Talin Kindin Vinculin recruitment } \\
\text { (cytoskeleton organization) }\end{array}$ & Extracellular matrix components & Animals \\
\hline & Toll, TLR & Myd88 recruitment & LPS, bact DNA, flagelin ... & Animals \\
\hline & 7TMR (GPCR) & Trimeric G-protein recruitment & alpha mating factor & Yeast \\
\hline & 7TMR (GPCR) & Trimeric G-protein recruitment & $\begin{array}{l}\text { hormones neuromediators } \\
\text { pheromones }\end{array}$ & Animals \\
\hline & $\begin{array}{l}\text { 7TMR (mGluR) } \\
\text { 7TMR (Frizzled) }\end{array}$ & $\begin{array}{c}\text { Homer recruitment } \\
\text { Dishevelled recruitment }\end{array}$ & $\begin{array}{l}\text { glutamate } \\
\text { Wnt }\end{array}$ & Animals \\
\hline
\end{tabular}




\section{Cell communications between uni- and multi-cellular organisms (Microbiotas)}

Microbiotas are sets of commensal microorganisms of animals or plants occupying a favorable environment and supplying in exchange numerous advantages to their shared host. It is most likely that these associations existed right from the origin of plant and metazoan lineages.

Many experiments are now designed to determine the interactions among microbes and between microbes and host, as these microorganisms have to interact on the one hand with one another (intraspecific and inter-specific quorum sensing), and on the other hand, with their shared host. Reciprocally, certain intestinal mammalian hormones mimic the action of bacterial signaling molecules, thus increasing the complexity level of the bidirectional communication between bacteria and the host.

\subsection{In animals}

Animals host microbiotas at different locations. In vertebrates, microbes mainly settle in their intestine but also their mouth or skin and various other sites. In Ecdysozoa (insects, arachnids, etc.) and lophotrochozoa (mollusks, annelids, etc.) microbiota are hosted at various locations such as in intestine or cuticle. Most insect guts contain relatively few microbial species as compared to mammals, but some insects harbor large gut communities of specialized bacteria. Others are colonized only opportunistically by bacteria from their environments. Microbiota in animals, have significant influences on endocrine, nervous and immune systems..

The gut microbiota is not just a random set of microorganisms, but rather, a complex community that plays critical roles in the host physiology. Commensal microorganisms are required for the maturation of the immune system, which "learns" to differentiate them from pathogenic ones.

In mammals, the intestinal microbiota is a dense community of cells (10 - 100 times the number of own host's cells), comprising aerobic and anaerobic bacteria, archeas, viruses, fungi, and other microbial eukaryotes.

\subsubsection{Bacteria in animals}

The communications of microbiota bacteria with host's cells are highly diverse affecting not only local intestinal functions but also general integrated functions.

The best-known bacterial recognition patterns are lipopolysaccharide (LPS) and peptidoglycan (PG), which act through binding with host pattern recognition receptors (PRRs), including Toll (Drosophila), Toll-like receptors TLR (vertebrates), and C-type lectin receptors CLRs (vertebrates). In vertebrates, membrane TLRs of the epithelial and lymphoid cells of the small intestine, which are responsible for innate intestinal immunity, differentiate microbiota microorganisms, and promote immunological tolerance towards them [157].

Moreover, chemical mimicry of animals' signaling molecules such as neuromediators or hormones, can be present in commensal bacteria. For example, $N$-acyl amide synthase in commensal bacteria produce lipids, such as endocannabinoids, which interact with GPCRs involved in gastrointestinal 
tract physiology [158]. Some bacterial agonists regulate metabolic hormones and glucose homeostasis as efficiently as human ligands.

In Drosophila melanogaster, the commensal gut microbial community inhibits the immune deficiency (Imd) pathway to avoid defensine production against them [159]. Peptidoglycans are mostly released when bacteria divide and are, therefore, a signature of bacterial cell division rather than merely bacterial presence. Consequently, transient colonization with a high load of pathogenic bacteria strong Imd response, while chronic, low-dose exposure to commensal bacteria instead stimulates Imd-dependent inhibition of the defensines production $[159,160]$.

The mammalian gut microbiota not only affects the host's immune system but also its autonomous $[161,162]$ and central $[163,164]$ nervous systems, in particular, via the vagus nerve from the intestine towards the hypothalamus, where it controls the host's appetite [165] and other behaviors [166].

\subsubsection{Fungi in animals}

Substances such as pyrazines, produced by ants' fungal microbiota, are used as a guide for individuals to find their way back to the anthill. The leaves carried to their nests by these leafcutter ants serve as a substrate for the cultivation of Leucoagaricus gongylophorous, the fungal species on which they specifically feed. However, another fungus species can impair the ant colony's viability by growing on the fungus they eat. But the ants harbor a symbiotic bacteria that produce compounds that can kill the parasitic fungi without damaging the food source. Therefore, microbiotic bacteria influence not only each ant's physiology but also the whole colony's behavior for its food resource (tracks back to the nest and food protection inside it). In the model species Drosophila, behavioral responses to 25 pyrazines vary widely despite their chemical similarity, ranging from strong, attractive responses to no response at all. Two olfactory receptors in Drosophila, Or33b and Or59a, yield remarkably long-lasting responses to certain pyrazines [167].

\subsection{In plants.}

The conquest of land by terrestrial plants occurred thanks to their interactions with fungi, and the survival of animals and plants is dependent on their respective microbiota. It is thus interesting to consider which molecular communication tools are present in unicellular and/or multicellular species, and how these mechanisms ensure optimal cell interactions favoring their respective survival and joint expansion.

The rhizobiota (root microbiota) is the set of the organisms of the ground (bacteria, mushrooms, virus, etc.) interacting with plant roots and so supplying them with many compounds that they do not synthesize. The term rhizobium is often used instead of rhizobiota. There are two types of symbioses with plants roots, mycorrhiza with fungi in almost all plants, and rhizobium with bacteria, mostly in the form of nodules in leguminoses.

Plants contain a significant number of PRRs that share remarkable structural and functional similarity with drosophila Toll and mammalian TLRs recognizing various pathogens or mediators. They are either membrane receptors with intrinsic intracytoplasmic kinase activity (RLKs) or non-kinase membrane receptors (RLPs) able to recruit RLKs and cytoplasmic kinases [168]. 
Plants are also able to cope with their microbiota through the emission of extracellular vesicles [86] and complex cross-talks through their respective secretomes to constitute functional holobionts [169].

\subsubsection{Fungi in plants}

Mycorrhiza (symbiosis of mushrooms with plant roots) is considered to be at the origin of the colonization of the dry land by water plants, approximately 450 million years ago. Indeed the widespread mycorrhization, together with the fossil record, indicates that plants and fungi have evolved in a mycorrhizal relationship since the colonization of land by early plants. More than $90 \%$ of the living land plants are capable of forming a mycorrhizal symbiosis, and a non-mycorrhizal status is an exception. Besides, the mycorrhizal network allows communications between plants of the same species or different species. There are two types of mycorrhization: arbuscular mycorrhizae (AM) and ectomycorrhizae (EM):

The arbuscular mycorrhizal (AM) fungi have developed a symbiotic relationship with most $(>80 \%)$ land plants; this is highly beneficial for the uptake of minerals and water from the soil by plants $[170,171]$ and for providing carbon sources to fungi. Hormones from the plants play a prominent role in AM establishment [172]. In AM, fungal hyphae penetrate inside the cortical tissues of roots, between the cell wall and plasma membrane. They display intracellular coils, vesicles, and arbuscules as well as lysis of the fungus inside the host cells.

Although AM interactions are physically restricted to the roots, they influence the whole-plant performance. Indeed, changes in foliar levels of carbohydrates, proteins, and amino acids, as well as secondary metabolites and phytohormones respond to AM inoculation. Blumenol C or its derivatives found in leaves is produced only in the roots of AM symbiotic plants and subsequently transported up to the shoots or leaves [173].

Ectomycorrhizae (EM) develop a fungal system close to the roots; they form a mantle that surrounds short roots and a network (called Hartig net) that penetrates between the roots cortical cells. The establishment of mycorrhization requires complex dialogue between the two partners, including the perception by the roots of specific lipo-chitooligosaccharides (LCOs), called Myc-LCO, secreted by fungi.

Fungal His-kinase receptors share a high degree of similarity with receptors for plant hormones (ethylene and cytokinin receptors). Importantly, these phytohormone receptor homologs were present in early fungi and must have played an essential role in their interaction with plants, leading to their joint conquest of land. The exact role of auxin in plant-fungus interactions is still elusive, but several studies indicate that auxin plays beneficial roles in fungal symbioses. Mutualistic fungi modify auxin biosynthesis and transport, thus promoting plant growth [174]. Some ectomycorrhizal fungi evolved from root endophytes coming from accompanying trees [175] thus participating in plant-plant interactions. 


\subsubsection{Bacteria in plants}

Two groups of bacteria can induce the formation of roots nitrogen-fixing nodules: proteobacteria called rhizobia, which associate with Legumes ( 20000 species) or actinobacteria, which can interact with approximately 220 species, belonging to eight different families called actinorhizal plants [176]. The rhizobium-legume symbiosis provides sufficient fixed nitrogen for legumes to grow and reproduce in $\mathrm{N}$-poor soils, and the nodules become a source of photosynthetic carbon to bacteria. First, immature and growing root hair cells are subjected to bacterial infection, and secondly, cortical cells near these infections dedifferentiate and become a nodule [177]. In such legume nodules, specialized cells are present that can contain thousands of bacteria, which are always surrounded by a plant membrane that forms a symbiotic interface.

In rhizobium-induced nodule organogenesis, the first signal comes from the roots and is a cocktail of flavonoids. These flavonoids stimulate the synthesis of nodulation (Nod) factors by the bacteria which cause around them, the formation of nodules by roots. Nod factors are LCOs that act via the hetero-dimerization of root membrane receptors, among which a Ser/Thr protein-kinase receptor and a calcium-and calmodulin-dependent kinase (CCaMK) that is activated by Nod factor-induced calcium oscillations in the nucleus [178]. CCaMK appears to play a pivotal role as intrinsically active forms of CCaMK induce the formation of spontaneous nodules in model legumes but also actinorhizal plants [179].

Root nodule formation is also regulated by several phytohormones (ethylene, gibberellins, auxin, cytokinins) as well as by signaling peptides, which control the development of new nodules, once a balance between nodule number, $\mathrm{N}$ fixation, and $\mathrm{C}$ demand reaches an acceptable equilibrium.

Nod factor secreted by compatible rhizobia triggers ethylene production. Ethylene production is an early and sustained nodulation response that acts at multiple stages to regulate infection, nodule organogenesis, and nitrogen fixation. Ethylene signaling is not required for Nod factor signaling, infection thread development, or nodule organogenesis, but it is for initiation of nitrogen fixation and negative regulation of nodulation [180-182]. In return, ethylene production by the plant can be modulated by Nod factors [183].

Gibberellins exert both positive and negative effects on nodulation because they act as suppressors of infection but as promoters of nodule organogenesis. Gibberellins and ethylene act through independent pathways in nodule development [184]. Auxin exhibits asymmetric distribution, which differently affects cell division, cell elongation, and cell differentiation, and this leads to root organ development, such as lateral root and nodule. Cytokinins also interact with the previous phytohormones in different ways to impact nodulation [185].

In brief, the communications between bacteria and plants for nodulation are of utmost importance for the establishment of symbiosis and consequently for plant development and survival in N-poor environment, and N-enrichment of soils. 
The root-nodule symbiosis [186] has concerned more numerous species than today, indicating its loss during evolution in multiple clades. Conserved co-regulated genes found within legumes paved the way for nodule formation and nitrogen fixation, suggesting that ancient orthologues and duplication events before the origin of legumes were preadapted for symbiosis [187]. The ability to decrease plant ethylene levels by the expression of the enzyme 1-aminocyclopropane-1-carboxylate (ACC) deaminase or via the production of rhizobitoxine, was found to be essential for leguminous plants to nodulate [188].

\subsubsection{Fungal mycorrhization and bacterial nodulation}

Signal transduction pathways leading to the establishment of different types of symbiosis share common plant hormone signaling components. Auxin is an important signal, as symbiosis establishment requires to reprogram multiple cellular fate [189].

Rhizobial bacteria Nod factors are LCOs perceived via plants' Lysin-Motif receptor-like kinases (LysM-RLKs). The LysM-RLKs can control the establishment of both the arbuscular mycorrhizal and the rhizobium-legume symbioses in response to signal molecules produced, respectively, by the fungal and bacterial symbiotic partners. Ancestral LysM-RLKs could have had dual symbiotic and immune roles and become subfunctionalized in immunity and/or for symbiosis [190]. It is recognized that mycorrhization preceded bacterial symbioses during the conquest of land by terrestrial plants [191].

\section{Cell communications between different multi-cellular organisms}

We will concentrate here on cell communications between individuals, animals, plants, or fungi belonging to different species. Thus, intra-species cell communications between individuals, which have been evoked before (pheromones, etc.), will not be considered here. In many cases, the term "communication" is exaggerated, where "detection" would be adequate. Indeed, in the present paper, we consider cell communications as integrated networks leading to a mutually beneficial equilibrium for two communicating species. Therefore, the detection of their hosts by parasites cannot be considered as communication. It is indeed invalid to compare kairomones to pheromones as the formers are only for the benefit of parasites, not for a mutual benefice.

\subsection{Cell communications between plants and fungi}

Arbuscular mycorrhization (AM) and ectomycorrhization (EM) have already been described above (microbiota). The secretomes of interacting plants and fungi include various metabolites and nucleic acids as well as peptides and proteins [169]. A number of these very diverse molecules are involved in the multidirectional communications taking place in the root-rhizospheric microbiota interactions.

\subsection{Cell communications between plants}

Plant volatile organic compounds (VOCs) such as sesquiterpenes are major vehicles of alarm information between plants in response to herbivore damage. VOCs may either directly affect cell membranes potentials and induce endogenous signal transduction cascades, or enter the cell and directly bind to co-repressors of stress-responsive genes [192]. 
It is interesting to point out that these communication channels can be private for plant species or even genotypes inside a species. By contrast, others are open to different species allowing information sharing and communication between them. This sharing may be favorable despite the cost of alarm signaling toward potential competitor species. Indeed, this sharing between plants allows cooperation in herbivore insect exclusion from their common neighborhood.

\subsection{Cell communications between animals and plants}

\subsubsection{Plants $>$ animals}

Plants broadcast signals either to attract or to repel animals (pollinating and herbivore animals, respectively). For pollination, most of the visitor species interact with only one or very few plant species. Mutualistic interactions imply sophisticated interplay of floral stimuli (scent, color) and the sensory systems of pollinators (bees, hawkmoths, geckos, etc.) among which vision and temperature play significant roles. Information transfer between plant species reduces the attraction of bee pollinators to herbivore-attacked plants or warned plants relative to undamaged/unwarned plants [193].

When wounded by herbivore insects, some plants like tomatoes produce the 18aa peptide systemin which binds to its receptor and stimulates the jasmonic acid cascade to stimulate the production of bad tasting chemicals to escape further consumption [194].

\subsubsection{Animals > plants}

The cell communications from animals to plants are not a very usual research field. Nevertheless, it has been recently reported that bees bite plants' leaves to induce their flowering to get access to pollen and that chemicals in the insects' saliva may be involved [195]. For the time being, the precise molecular and cellular mechanisms are not known.

\section{Conclusion:}

Cellular communications play pivotal roles in all uni- and multi-cellular species, leading to an outstanding variety of essential biological processes not only inside each species but also for numerous favorable interactions between uni- and multi-cellular species. These interactions have been made possible by the high degree of conservation of the basic mechanisms of many ligandreceptor pairs in evolutionary remote species. Moreover these inter-species communications have played an important role during Evolution and must have been selected when mutually beneficial.

\section{Abbreviations:}

ABC: ATP binding cassette; AHL: N-Acyl homoserine lactones; AI-2, AI-3: autoinducer-2, -3;

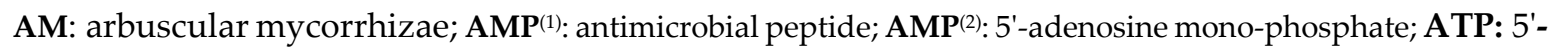
adenosine tri-phosphate; CAM: cell adhesion molecule; cAMP: 3'5'cyclic-AMP; CBP: CREB binding protein; CLR: C-type lectin receptor; CREB: cAMP-responsive element binding protein; CRP: cyclicAMP receptor protein; DAMP: damage-associated molecular pattern; ECD: extracellular domain; eDNA: extracellular DNA; EM: ectomycorrhizae; EV: extracellular vesicle; FSH: folliclestimulating hormone; GnRH: gonadotropin-releasing hormone; GPCR: G protein-coupled receptor; Hh: hedgehog; HSL: homoserine lactone; ICD: intracellular domain; IMD: immune deficiency pathway JAK: janus kinase; LH: luteinizing hormone; LRR: leucine-rich repeat; LysM-RLK; lysinmotif receptor-like kinase; (MAPK, MAPKK, MAPKKK: Mitogen-Activated Protein kinases; 
NO: nitrogen oxide; Nod: nodulation factor; PGN: peptidoglycan; PGRP: peptidoglycan-binding receptor protein; PRR: pattern recognition receptor; PTS: phosphotransferase system; QS: quorum sensing; RLK: receptor-like kinase; RLP: receptor-like protein; TCS: receptor-histidine-kinase twocomponent system; TNT: tunneling nanotubes; TLR: toll-like receptor; TNF: tumor-necrosis factor; VOC: volatile organic compound;

Funding: This research received no external funding

Acknowledgments: The authors thank the University of Tours (France) for the invitation to TMDN for a twomonth stay at the INRA laboratory in Nouzilly. We also thank the University of Quy Nhon (Viet Nam) for authorizing TMDN to leave her teaching duties during this period of time.

Conflicts of Interest: The authors declare no conflict of interest

\section{References}

1. Pearce, B.K.D.; Tupper, A.S.; Pudritz, R.E.; Higgs, P.G. Constraining the Time Interval for the Origin of Life on Earth. Astrobiology 2018, 18, 343-364, doi:10.1089/ast.2017.1674.

2. Czaran, T.; Konnyu, B.; Szathmary, E. Metabolically Coupled Replicator Systems: Overview of an RNA-world model concept of prebiotic evolution on mineral surfaces. J Theor Biol 2015, 381, 39-54, doi:10.1016/j.jtbi.2015.06.002.

3. Staps, M.; van Gestel, J.; Tarnita, C.E. Emergence of diverse life cycles and life histories at the origin of multicellularity. Nat Ecol Evol 2019, 3, 1197-1205, doi:10.1038/s41559-019-09400 .

4. Schrum, J.P.; Zhu, T.F.; Szostak, J.W. The origins of cellular life. Cold Spring Harb Perspect Biol 2010, 2, a002212, doi:10.1101/cshperspect.a002212.

5. Egel, R. Primal eukaryogenesis: on the communal nature of precellular States, ancestral to modern life. Life (Basel) 2012, 2, 170-212, doi:10.3390/life2010170.

6. Spitzer, J. Emergence of life from multicomponent mixtures of chemicals: the case for experiments with cycling physicochemical gradients. Astrobiology 2013, 13, 404-413, doi:10.1089/ast.2012.0924.

7. Grandchamp, A.; Monget, P. Synchronous birth is a dominant pattern in receptor-ligand evolution. BMC Genomics 2018, 19, 611, doi:10.1186/s12864-018-4977-2.

8. Vakirlis, N.; Acar, O.; Hsu, B.; Castilho Coelho, N.; Van Oss, S.B.; Wacholder, A.; MedetgulErnar, K.; Bowman, R.W., 2nd; Hines, C.P.; Iannotta, J., et al. De novo emergence of adaptive membrane proteins from thymine-rich genomic sequences. Nat Commun 2020, 11, 781, doi:10.1038/s41467-020-14500-z.

9. Lehnert, J.; Khadra, A. How Pulsatile Kisspeptin Stimulation and GnRH Autocrine Feedback Can Drive GnRH Secretion: A Modeling Investigation. Endocrinology 2019, 160, 1289-1306, doi:10.1210/en.2018-00947.

10. Lunenfeld, B.; Buhler, K. The neuro control of the ovarain cycle - a hypothesis. Gynecol Endocrinol 2018, 34, 278-282, doi:10.1080/09513590.2017.1405933.

11. Wojtowicz, H.; Prochnicka-Chalufour, A.; de Amorim, G.C.; Roudenko, O.; Simenel, C.; Malki, I.; Pehau-Arnaudet, G.; Gubellini, F.; Koutsioubas, A.; Perez, J., et al. Structural basis of the signalling through a bacterial membrane receptor HasR deciphered by an integrative approach. Biochem J 2016, 473, 2239-2248, doi:10.1042/BCJ20160131. 
12. Weigel, W.A.; Demuth, D.R. QseBC, a two-component bacterial adrenergic receptor and global regulator of virulence in Enterobacteriaceae and Pasteurellaceae. Mol Oral Microbiol 2016, 31, 379-397, doi:10.1111/omi.12138.

13. Cevheroglu, O.; Kumas, G.; Hauser, M.; Becker, J.M.; Son, C.D. The yeast Ste2p G proteincoupled receptor dimerizes on the cell plasma membrane. Biochim Biophys Acta Biomembr 2017, 1859, 698-711, doi:10.1016/j.bbamem.2017.01.008.

14. Mhatre, E.; Monterrosa, R.G.; Kovacs, A.T. From environmental signals to regulators: modulation of biofilm development in Gram-positive bacteria. J Basic Microbiol 2014, 54, 616-632, doi:10.1002/jobm.201400175.

15. Kavanaugh, J.S.; Flack, C.E.; Lister, J.; Ricker, E.B.; Ibberson, C.B.; Jenul, C.; Moormeier, D.E.; Delmain, E.A.; Bayles, K.W.; Horswill, A.R. Identification of Extracellular DNABinding Proteins in the Biofilm Matrix. MBio 2019, 10, doi:10.1128/mBio.01137-19.

16. Blakeman, J.T.; Morales-Garcia, A.L.; Mukherjee, J.; Gori, K.; Hayward, A.S.; Lant, N.J.; Geoghegan, M. Extracellular DNA Provides Structural Integrity to a Micrococcus luteus Biofilm. Langmuir 2019, 35, 6468-6475, doi:10.1021/acs.langmuir.9b00297.

17. Welsh, M.A.; Blackwell, H.E. Chemical probes of quorum sensing: from compound development to biological discovery. FEMS Microbiol Rev 2016, 40, 774-794, doi:10.1093/femsre/fuw009.

18. Talagrand-Reboul, E.; Jumas-Bilak, E.; Lamy, B. The Social Life of Aeromonas through Biofilm and Quorum Sensing Systems. Front Microbiol 2017, 8, 37, doi:10.3389/fmicb.2017.00037.

19. Papenfort, K.; Bassler, B.L. Quorum sensing signal-response systems in Gram-negative bacteria. Nat Rev Microbiol 2016, 14, 576-588, doi:10.1038/nrmicro.2016.89.

20. McCready, A.R.; Paczkowski, J.E.; Henke, B.R.; Bassler, B.L. Structural determinants driving homoserine lactone ligand selection in the Pseudomonas aeruginosa LasR quorumsensing receptor. Proc Natl Acad Sci U S A 2019, 116, 245-254, doi:10.1073/pnas.1817239116.

21. Naser, I.B.; Hoque, M.M.; Faruque, S.N.; Kamruzzaman, M.; Yamasaki, S.; Faruque, S.M. Vibrio cholerae strains with inactivated cqsS gene overproduce autoinducer-2 which enhances resuscitation of dormant environmental V. cholerae. PLoS One 2019, 14, e0223226, doi:10.1371/journal.pone.0223226.

22. Tourneroche, A.; Lami, R.; Hubas, C.; Blanchet, E.; Vallet, M.; Escoubeyrou, K.; Paris, A.; Prado, S. Bacterial-Fungal Interactions in the Kelp Endomicrobiota Drive Autoinducer-2 Quorum Sensing. Front Microbiol 2019, 10, 1693, doi:10.3389/fmicb.2019.01693.

23. Verbeke, F.; De Craemer, S.; Debunne, N.; Janssens, Y.; Wynendaele, E.; Van de Wiele, C.; De Spiegeleer, B. Peptides as Quorum Sensing Molecules: Measurement Techniques and Obtained Levels In vitro and In vivo. Front Neurosci 2017, 11, 183, doi:10.3389/fnins.2017.00183.

24. Krypotou, E.; Scortti, M.; Grundstrom, C.; Oelker, M.; Luisi, B.F.; Sauer-Eriksson, A.E.; Vazquez-Boland, J. Control of Bacterial Virulence through the Peptide Signature of the Habitat. Cell Rep 2019, 26, 1815-1827 e1815, doi:10.1016/j.celrep.2019.01.073.

25. He, L.; Dai, K.; Wen, X.; Ding, L.; Cao, S.; Huang, X.; Wu, R.; Zhao, Q.; Huang, Y.; Yan, Q., et al. QseC Mediates Osmotic Stress Resistance and Biofilm Formation in Haemophilus parasuis. Front Microbiol 2018, 9, 212, doi:10.3389/fmicb.2018.00212. 
26. Novak, E.A.; Shao, H.; Daep, C.A.; Demuth, D.R. Autoinducer-2 and QseC control biofilm formation and in vivo virulence of Aggregatibacter actinomycetemcomitans. Infect Immun 2010, 78, 2919-2926, doi:10.1128/IAI.01376-09.

27. Yang, K.; Meng, J.; Huang, Y.C.; Ye, L.H.; Li, G.J.; Huang, J.; Chen, H.M. The role of the QseC quorum-sensing sensor kinase in epinephrine-enhanced motility and biofilm formation by Escherichia coli. Cell Biochem Biophys 2014, 70, 391-398, doi:10.1007/s12013-0149924-5.

28. van Kessel, J.C. PQS Signaling for More than a Quorum: the Collective Stress Response Protects Healthy Pseudomonas aeruginosa Populations. J Bacteriol 2019, 201, doi:10.1128/JB.00568-19.

29. Holm, A.; Vikstrom, E. Quorum sensing communication between bacteria and human cells: signals, targets, and functions. Front Plant Sci 2014, 5, 309, doi:10.3389/fpls.2014.00309.

30. Prindle, A.; Liu, J.; Asally, M.; Ly, S.; Garcia-Ojalvo, J.; Suel, G.M. Ion channels enable electrical communication in bacterial communities. Nature 2015, 527, 59-63, doi:10.1038/nature15709.

31. Erez, Z.; Steinberger-Levy, I.; Shamir, M.; Doron, S.; Stokar-Avihail, A.; Peleg, Y.; Melamed, S.; Leavitt, A.; Savidor, A.; Albeck, S., et al. Communication between viruses guides lysislysogeny decisions. Nature 2017, 541, 488-493, doi:10.1038/nature21049.

32. Stokar-Avihail, A.; Tal, N.; Erez, Z.; Lopatina, A.; Sorek, R. Widespread Utilization of Peptide Communication in Phages Infecting Soil and Pathogenic Bacteria. Cell Host Microbe 2019, 25, 746-755 e745, doi:10.1016/j.chom.2019.03.017.

33. Laganenka, L.; Sander, T.; Lagonenko, A.; Chen, Y.; Link, H.; Sourjik, V. Quorum Sensing and Metabolic State of the Host Control Lysogeny-Lysis Switch of Bacteriophage T1. MBio 2019, 10, doi:10.1128/mBio.01884-19.

34. Chow, J.; Dionne, H.M.; Prabhakar, A.; Mehrotra, A.; Somboonthum, J.; Gonzalez, B.; Edgerton, M.; Cullen, P.J. Aggregate Filamentous Growth Responses in Yeast. mSphere 2019, 4, doi:10.1128/mSphere.00702-18.

35. Veelders, M.; Bruckner, S.; Ott, D.; Unverzagt, C.; Mosch, H.U.; Essen, L.O. Structural basis of flocculin-mediated social behavior in yeast. Proc Natl Acad Sci U S A 2010, 107, 2251122516, doi:10.1073/pnas.1013210108.

36. Sebaa, S.; Boucherit-Otmani, Z.; Courtois, P. Effects of tyrosol and farnesol on Candida albicans biofilm. Mol Med Rep 2019, 19, 3201-3209, doi:10.3892/mmr.2019.9981.

37. Padder, S.A.; Prasad, R.; Shah, A.H. Quorum sensing: A less known mode of communication among fungi. Microbiol Res 2018, 210, 51-58, doi:10.1016/j.micres.2018.03.007.

38. Albuquerque, P.; Nicola, A.M.; Nieves, E.; Paes, H.C.; Williamson, P.R.; Silva-Pereira, I.; Casadevall, A. Quorum sensing-mediated, cell density-dependent regulation of growth and virulence in Cryptococcus neoformans. MBio 2013, 5, e00986-00913, doi:10.1128/mBio.0098613.

39. Vivas, W.; Leonhardt, I.; Hunniger, K.; Hader, A.; Marolda, A.; Kurzai, O. Multiple Signaling Pathways Involved in Human Dendritic Cell Maturation Are Affected by the Fungal Quorum-Sensing Molecule Farnesol. J Immunol 2019, 203, 2959-2969, doi:10.4049/jimmunol.1900431. 
40. Fischer, M.S.; Glass, N.L. Communicate and Fuse: How Filamentous Fungi Establish and Maintain an Interconnected Mycelial Network. Front Microbiol 2019, 10, 619, doi:10.3389/fmicb.2019.00619.

41. Belozerskaya, T.A. Cell-to-cell communication in differentiation of mycelial fungi. Membr Cell Biol 1998, 11, 831-840.

42. Albuquerque, P.; Casadevall, A. Quorum sensing in fungi--a review. Med Mycol 2012, 50, 337-345, doi:10.3109/13693786.2011.652201.

43. Fleissner, A.; Herzog, S. Signal exchange and integration during self-fusion in filamentous fungi. Semin Cell Dev Biol 2016, 57, 76-83, doi:10.1016/j.semcdb.2016.03.016.

44. Martin, S.G. Molecular mechanisms of chemotropism and cell fusion in unicellular fungi. J Cell Sci 2019, 132, doi:10.1242/jcs.230706.

45. Bielska, E.; May, R.C. Extracellular vesicles of human pathogenic fungi. Curr Opin Microbiol 2019, 52, 90-99, doi:10.1016/j.mib.2019.05.007.

46. Miranda, E.R.; Nam, E.A.; Kuspa, A.; Shaulsky, G. The ABC transporter, AbcB3, mediates cAMP export in D. discoideum development. Dev Biol 2015, 397, 203-211, doi:10.1016/j.ydbio.2014.11.006.

47. Goldbeter, A. Oscillations and waves of cyclic AMP in Dictyostelium: a prototype for spatio-temporal organization and pulsatile intercellular communication. Bull Math Biol 2006, 68, 1095-1109, doi:10.1007/s11538-006-9090-z.

48. Yamada, Y.; Schaap, P. Cyclic AMP induction of Dictyostelium prespore gene expression requires autophagy. Dev Biol 2019, 452, 114-126, doi:10.1016/j.ydbio.2019.04.017.

49. Asghar, A.; Groth, M.; Siol, O.; Gaube, F.; Enzensperger, C.; Glockner, G.; Winckler, T. Developmental gene regulation by an ancient intercellular communication system in social amoebae. Protist 2012, 163, 25-37, doi:10.1016/j.protis.2010.12.002.

50. Silvester, E.; Young, J.; Ivens, A.; Matthews, K.R. Interspecies quorum sensing in coinfections can manipulate trypanosome transmission potential. Nat Microbiol 2017, 2, 14711479, doi:10.1038/s41564-017-0014-5.

51. Armaleo, D.; Muller, O.; Lutzoni, F.; Andresson, O.S.; Blanc, G.; Bode, H.B.; Collart, F.R.; Dal Grande, F.; Dietrich, F.; Grigoriev, I.V., et al. The lichen symbiosis re-viewed through the genomes of Cladonia grayi and its algal partner Asterochloris glomerata. BMC Genomics 2019, 20, 605, doi:10.1186/s12864-019-5629-x.

52. Joneson, S.; Armaleo, D.; Lutzoni, F. Fungal and algal gene expression in early developmental stages of lichen-symbiosis. Mycologia 2011, 103, 291-306, doi:10.3852/10-064.

53. Chekanov, K.; Feoktistov, A.; Lobakova, E. Spatial organization of the three-component lichen Peltigera aphthosa in functional terms. Physiol Plant 2017, 160, 328-338, doi:10.1111/ppl.12552.

54. Manoharan, S.S.; Miao, V.P.; Andresson, O.S. LEC-2, a highly variable lectin in the lichen Peltigera membranacea. Symbiosis 2012, 58, 91-98, doi:10.1007/s13199-012-0206-y.

55. Garg, N.; Zeng, Y.; Edlund, A.; Melnik, A.V.; Sanchez, L.M.; Mohimani, H.; Gurevich, A.; Miao, V.; Schiffler, S.; Lim, Y.W., et al. Spatial Molecular Architecture of the Microbial Community of a Peltigera Lichen. mSystems 2016, 1, doi:10.1128/mSystems.00139-16. 
56. Sigurbjornsdottir, M.A.; Andresson, O.S.; Vilhelmsson, O. Nutrient scavenging activity and antagonistic factors of non-photobiont lichen-associated bacteria: a review. World J Microbiol Biotechnol 2016, 32, 68, doi:10.1007/s11274-016-2019-2.

57. Kashefi, K.; Lovley, D.R. Extending the upper temperature limit for life. Science 2003, 301, 934, doi:10.1126/science.1086823.

58. Abramov, O.; Mojzsis, S.J. Microbial habitability of the Hadean Earth during the late heavy bombardment. Nature 2009, 459, 419-422, doi:10.1038/nature08015.

59. Gelsinger, D.R.; Uritskiy, G.; Reddy, R.; Munn, A.; Farney, K.; DiRuggiero, J. Regulatory Noncoding Small RNAs Are Diverse and Abundant in an Extremophilic Microbial Community. mSystems 2020, 5, doi:10.1128/mSystems.00584-19.

60. Babonis, L.S.; Martindale, M.Q. Phylogenetic evidence for the modular evolution of metazoan signalling pathways. Philos Trans R Soc Lond B Biol Sci 2017, 372, doi:10.1098/rstb.2015.0477.

61. Li, P.; Elowitz, M.B. Communication codes in developmental signaling pathways. Development 2019, 146, doi:10.1242/dev.170977.

62. Brodsky, V.Y. Direct cell-cell communications and social behavior of cells in mammals, protists, and bacteria. Possible causes of multicellularity. Russ J Dev Biol+ 2009, 40, 69-82, doi:10.1134/S1062360409020027.

63. Beyer, E.C.; Berthoud, V.M. Gap junction gene and protein families: Connexins, innexins, and pannexins. Biochim Biophys Acta Biomembr 2018, 1860, 5-8, doi:10.1016/j.bbamem.2017.05.016.

64. Sanchez, A.; Castro, C.; Flores, D.L.; Gutierrez, E.; Baldi, P. Gap Junction Channels of Innexins and Connexins: Relations and Computational Perspectives. Int J Mol Sci 2019, 20, doi:10.3390/ijms20102476.

65. Han, X.; Huang, L.J.; Feng, D.; Jiang, W.; Miu, W.; Li, N. Plasmodesmata-Related Structural and Functional Proteins: The Long Sought-After Secrets of a Cytoplasmic Channel in Plant Cell Walls. Int J Mol Sci 2019, 20, doi:10.3390/ijms20122946.

66. Goodman, S.; Naphade, S.; Khan, M.; Sharma, J.; Cherqui, S. Macrophage polarization impacts tunneling nanotube formation and intercellular organelle trafficking. Sci Rep 2019, 9, 14529, doi:10.1038/s41598-019-50971-x.

67. Haglund, K.; Nezis, I.P.; Stenmark, H. Structure and functions of stable intercellular bridges formed by incomplete cytokinesis during development. Commun Integr Biol 2011, 4, 1-9, doi:10.4161/cib.4.1.13550.

68. Ganusova, E.E.; Burch-Smith, T.M. Review: Plant-pathogen interactions through the plasmodesma prism. Plant Sci 2019, 279, 70-80, doi:10.1016/j.plantsci.2018.05.017.

69. Patel, H.; Bhartiya, D. Direct action of FSH on testicular stem cells. Stem Cell Res Ther 2019, 10, 261, doi:10.1186/s13287-019-1390-y.

70. Dupont, M.; Souriant, S.; Lugo-Villarino, G.; Maridonneau-Parini, I.; Verollet, C. Tunneling Nanotubes: Intimate Communication between Myeloid Cells. Front Immunol 2018, 9, 43, doi:10.3389/fimmu.2018.00043.

71. Baidya, A.K.; Bhattacharya, S.; Dubey, G.P.; Mamou, G.; Ben-Yehuda, S. Bacterial nanotubes: a conduit for intercellular molecular trade. Curr Opin Microbiol 2018, 42, 1-6, doi:10.1016/j.mib.2017.08.006. 
72. Onfelt, B.; Nedvetzki, S.; Benninger, R.K.; Purbhoo, M.A.; Sowinski, S.; Hume, A.N.; Seabra, M.C.; Neil, M.A.; French, P.M.; Davis, D.M. Structurally distinct membrane nanotubes between human macrophages support long-distance vesicular traffic or surfing of bacteria. J Immunol 2006, 177, 8476-8483, doi:10.4049/jimmunol.177.12.8476.

73. Niedenberger, B.A.; Cook, K.; Baena, V.; Serra, N.D.; Velte, E.K.; Agno, J.E.; Litwa, K.A.; Terasaki, M.; Hermann, B.P.; Matzuk, M.M., et al. Dynamic cytoplasmic projections connect mammalian spermatogonia in vivo. Development 2018, 145, doi:10.1242/dev.161323.

74. Patel, H.; Bhartiya, D.; Parte, S. Further characterization of adult sheep ovarian stem cells and their involvement in neo-oogenesis and follicle assembly. J Ovarian Res 2018, 11, 3, doi:10.1186/s13048-017-0377-5.

75. Urbisz, A.Z.; Chajec, L.; Ito, M.; Ito, K. The ovary organization in the marine limnodriloidin Thalassodrilides cf. briani (Annelida: Clitellata: Naididae) resembles the ovary of freshwater tubificins. Zoology (Jena) 2018, 128, 16-26, doi:10.1016/j.zool.2018.05.004.

76. Wang, C.Y.; Li, X.; Wu, Q.F.; Wang, X.Y. Cytoplasmic channels and their association with plastids in male meiocytes of tobacco, onion and lily. Cell Biol Int 2006, 30, 406-411, doi:10.1016/j.cellbi.2006.01.003.

77. Amini, R.; Chartier, N.T.; Labbe, J.C. Syncytium biogenesis: It's all about maintaining good connections. Worm 2015, 4, e992665, doi:10.4161/21624054.2014.992665.

78. Gonzalez Santander, R.; Toledo Lobo, M.V.; Martinez Alonso, F.J.; Martinez Cuadrado, G. Fusion mechanism of the myoblasts in the myotome of the chick embryo. Histol Histopathol 1993, 8, 471-490.

79. Zhang, Y.; Yang, H. A simple and robust fluorescent labeling method to quantify trophoblast fusion. Placenta 2019, 77, 16-18, doi:10.1016/j.placenta.2019.01.016.

80. Milano-Foster, J.; Ray, S.; Home, P.; Ganguly, A.; Bhattacharya, B.; Bajpai, S.; Pal, A.; Mason, C.W.; Paul, S. Regulation of human trophoblast syncytialization by histone demethylase LSD1. J Biol Chem 2019, 10.1074/jbc.RA119.010518, doi:10.1074/jbc.RA119.010518.

81. Roper, M.; Simonin, A.; Hickey, P.C.; Leeder, A.; Glass, N.L. Nuclear dynamics in a fungal chimera. Proc Natl Acad Sci U S A 2013, 110, 12875-12880, doi:10.1073/pnas.1220842110.

82. Dundon, S.E.; Chang, S.S.; Kumar, A.; Occhipinti, P.; Shroff, H.; Roper, M.; Gladfelter, A.S. Clustered nuclei maintain autonomy and nucleocytoplasmic ratio control in a syncytium. Mol Biol Cell 2016, 27, 2000-2007, doi:10.1091/mbc.E16-02-0129.

83. Meldolesi, J. Exosomes and Ectosomes in Intercellular Communication. Curr Biol 2018, 28, R435-R444, doi:10.1016/j.cub.2018.01.059.

84. Nachury, M.V.; Mick, D.U. Establishing and regulating the composition of cilia for signal transduction. Nat Rev Mol Cell Biol 2019, 20, 389-405, doi:10.1038/s41580-019-0116-4.

85. Cui, Y.; Gao, J.; He, Y.; Jiang, L. Plant extracellular vesicles. Protoplasma 2019, 10.1007/s00709-019-01435-6, doi:10.1007/s00709-019-01435-6.

86. Spinler, J.K.; Karri, V.; Hirschi, K.D. Planting the Microbiome. Trends Microbiol 2019, 27, $90-$ 93, doi:10.1016/j.tim.2018.12.001.

87. Gill, S.; Catchpole, R.; Forterre, P. Extracellular membrane vesicles in the three domains of life and beyond. FEMS Microbiol Rev 2019, 43, 273-303, doi:10.1093/femsre/fuy042. 
88. Han, J.H.; Batey, S.; Nickson, A.A.; Teichmann, S.A.; Clarke, J. The folding and evolution of multidomain proteins. Nat Rev Mol Cell Biol 2007, 8, 319-330, doi:10.1038/nrm2144.

89. Ko, J. The leucine-rich repeat superfamily of synaptic adhesion molecules: LRRTMs and Slitrks. Mol Cells 2012, 34, 335-340, doi:10.1007/s10059-012-0113-3.

90. Pellenc, D.; Schmitt, E.; Gallet, O. Purification of a plant cell wall fibronectin-like adhesion protein involved in plant response to salt stress. Protein Expr Purif 2004, 34, 208-214, doi:10.1016/j.pep.2003.11.011.

91. O'Farrell, T.J.; Pourmotabbed, T. Identification of structural elements important for matrix metalloproteinase type $\mathrm{V}$ collagenolytic activity as revealed by chimeric enzymes. Role of fibronectin-like domain and active site of gelatinase B. J Biol Chem 2000, 275, 27964-27972, doi:10.1074/jbc.M003936200.

92. Chen, J.; Wang, B.; Wu, Y. Structural Characterization and Function Prediction of Immunoglobulin-like Fold in Cell Adhesion and Cell Signaling. J Chem Inf Model 2018, 58, 532-542, doi:10.1021/acs.jcim.7b00580.

93. Cota, E.; Steward, A.; Fowler, S.B.; Clarke, J. The folding nucleus of a fibronectin type III domain is composed of core residues of the immunoglobulin-like fold. J Mol Biol 2001, 305, 1185-1194, doi:10.1006/jmbi.2000.4378.

94. Muller, R.; Jenny, A.; Stanley, P. The EGF repeat-specific O-GlcNAc-transferase Eogt interacts with notch signaling and pyrimidine metabolism pathways in Drosophila. PLoS One 2013, 8, e62835, doi:10.1371/journal.pone.0062835.

95. Ensslin, M.A.; Shur, B.D. Identification of mouse sperm SED1, a bimotif EGF repeat and discoidin-domain protein involved in sperm-egg binding. Cell 2003, 114, 405-417, doi:10.1016/s0092-8674(03)00643-3.

96. Wang, H.; Feng, Z.; Xu, B. Intercellular Instructed-Assembly Mimics Protein Dynamics To Induce Cell Spheroids. J Am Chem Soc 2019, 141, 7271-7274, doi:10.1021/jacs.9b03346.

97. Young, B.M.; Shankar, K.; Tho, C.K.; Pellegrino, A.R.; Heise, R.L. Laminin-driven Epac/Rap1 regulation of epithelial barriers on decellularized matrix. Acta Biomater 2019, 10.1016/j.actbio.2019.10.009, doi:10.1016/j.actbio.2019.10.009.

98. Zhang, Z.; Cai, J.; Li, Y.; He, Y.; Dong, Z.; Dai, J.; Lu, F. External Volume Expansion Adjusted Adipose Stem Cell by Shifting the Ratio of Fibronectin to Laminin. Tissue Eng Part A 2019, 10.1089/ten.TEA.2019.0095, doi:10.1089/ten.TEA.2019.0095.

99. Polisetti, N.; Zenkel, M.; Menzel-Severing, J.; Kruse, F.E.; Schlotzer-Schrehardt, U. Cell Adhesion Molecules and Stem Cell-Niche-Interactions in the Limbal Stem Cell Niche. Stem Cells 2016, 34, 203-219, doi:10.1002/stem.2191.

100. Andreadis, D.; Epivatianos, A.; Poulopoulos, A.; Nomikos, A.; Christidis, K.; Papazoglou, G.; Antoniades, D.; Barbatis, C. Immunohistochemical detection of the expression of the cell adhesion molecules E-cadherin, desmoglein-2, beta4-integrin, ICAM-1 and HCAM (CD44s) in Warthin's tumour of the parotid gland. Oral Oncol 2005, 41, 799-805, doi:10.1016/j.oraloncology.2005.03.007.

101. Woods, A.; Wang, G.; Beier, F. Regulation of chondrocyte differentiation by the actin cytoskeleton and adhesive interactions. J Cell Physiol 2007, 213, 1-8, doi:10.1002/jcp.21110.

102. Thalhammer, A.; Cingolani, L.A. Cell adhesion and homeostatic synaptic plasticity. Neuropharmacology 2014, 78, 23-30, doi:10.1016/j.neuropharm.2013.03.015. 
103. Mizuta, Y.; Higashiyama, T. Chemical signaling for pollen tube guidance at a glance. J Cell Sci 2018, 131, doi:10.1242/jcs.208447.

104. Buckeridge, M.S. The evolution of the Glycomic Codes of extracellular matrices. Biosystems 2018, 164, 112-120, doi:10.1016/j.biosystems.2017.10.003.

105. Venereau, E.; Ceriotti, C.; Bianchi, M.E. DAMPs from Cell Death to New Life. Front Immunol 2015, 6, 422, doi:10.3389/fimmu.2015.00422.

106. Hill, L.M.; Gavala, M.L.; Lenertz, L.Y.; Bertics, P.J. Extracellular ATP may contribute to tissue repair by rapidly stimulating purinergic receptor X7-dependent vascular endothelial growth factor release from primary human monocytes. J Immunol 2010, 185, 3028-3034, doi:10.4049/jimmunol.1001298.

107. Nolan, L.M.; Cavaliere, R.; Turnbull, L.; Whitchurch, C.B. Extracellular ATP inhibits twitching motility-mediated biofilm expansion by Pseudomonas aeruginosa. BMC Microbiol 2015, 15, 55, doi:10.1186/s12866-015-0392-x.

108. Magni, G.; Ceruti, S. The role of adenosine and P2Y receptors expressed by multiple cell types in pain transmission. Brain Res Bull 2019, 151, 132-143, doi:10.1016/j.brainresbull.2019.02.011.

109. Schmid, R.; Evans, R.J. ATP-Gated P2X Receptor Channels: Molecular Insights into Functional Roles. Annu Rev Physiol 2019, 81, 43-62, doi:10.1146/annurev-physiol-020518114259.

110. Giuliani, A.L.; Sarti, A.C.; Di Virgilio, F. Extracellular nucleotides and nucleosides as signalling molecules. Immunol Lett 2019, 205, 16-24, doi:10.1016/j.imlet.2018.11.006.

111. Sun, J.; Zhang, C.; Zhang, X.; Deng, S.; Zhao, R.; Shen, X.; Chen, S. Extracellular ATP signaling and homeostasis in plant cells. Plant Signal Behav 2012, 7, 566-569, doi:10.4161/psb.19857.

112. Gakière, B.; Hao, J.; de Bont, L.; Pétriacq, P.; Nunes-Nesi, A.; Fernie, A.R. NAD+ Biosynthesis and Signaling in Plants. Critical Reviews in Plant Sciences 2018, 37, 259-307, doi:10.1080/07352689.2018.1505591.

113. Yu, A.; Lau, A.Y. Glutamate and Glycine Binding to the NMDA Receptor. Structure 2018, 26, 1035-1043 e1032, doi:10.1016/j.str.2018.05.004.

114. Zhao, D.; Yu, Y.; Shen, Y.; Liu, Q.; Zhao, Z.; Sharma, R.; Reiter, R.J. Melatonin Synthesis and Function: Evolutionary History in Animals and Plants. Front Endocrinol (Lausanne) 2019, 10, 249, doi:10.3389/fendo.2019.00249.

115. Cotnoir-White, D.; Laperriere, D.; Mader, S. Evolution of the repertoire of nuclear receptor binding sites in genomes. Mol Cell Endocrinol 2011, 334, 76-82, doi:10.1016/j.mce.2010.10.021.

116. Wu, Y.; Zhang, D.; Chu, J.Y.; Boyle, P.; Wang, Y.; Brindle, I.D.; De Luca, V.; Despres, C. The Arabidopsis NPR1 protein is a receptor for the plant defense hormone salicylic acid. Cell Rep 2012, 1, 639-647, doi:10.1016/j.celrep.2012.05.008.

117. Zhai, Q.; Li, L.; An, C.; Li, C. Conserved function of mediator in regulating nuclear hormone receptor activation between plants and animals. Plant Signal Behav 2018, 13, e1403709, doi:10.1080/15592324.2017.1403709.

118. Reeves, D.C.; Lummis, S.C. The molecular basis of the structure and function of the 5-HT3 receptor: a model ligand-gated ion channel (review). Mol Membr Biol 2002, 19, 11-26. 
119. Olsen, R.W. GABAA receptor: Positive and negative allosteric modulators. Neuropharmacology 2018, 136, 10-22, doi:10.1016/j.neuropharm.2018.01.036.

120. Diwanji, D.; Thaker, T.; Jura, N. More than the sum of the parts: Toward full-length receptor tyrosine kinase structures. IUBMB Life 2019, 71, 706-720, doi:10.1002/iub.2060.

121. Josso, N.; di Clemente, N. Serine/threonine kinase receptors and ligands. Curr Opin Genet Dev 1997, 7, 371-377, doi:10.1016/s0959-437x(97)80151-7.

122. Kostas, M.; Haugsten, E.M.; Zhen, Y.; Sorensen, V.; Szybowska, P.; Fiorito, E.; Lorenz, S.; Jones, N.; de Souza, G.A.; Wiedlocha, A., et al. Protein Tyrosine Phosphatase Receptor Type G (PTPRG) Controls Fibroblast Growth Factor Receptor (FGFR) 1 Activity and Influences Sensitivity to FGFR Kinase Inhibitors. Mol Cell Proteomics 2018, 17, 850-870, doi:10.1074/mcp.RA117.000538.

123. Misono, K.S.; Philo, J.S.; Arakawa, T.; Ogata, C.M.; Qiu, Y.; Ogawa, H.; Young, H.S. Structure, signaling mechanism and regulation of the natriuretic peptide receptor guanylate cyclase. FEBS J 2011, 278, 1818-1829, doi:10.1111/j.1742-4658.2011.08083.x.

124. Duda, T.; Pertzev, A.; Sharma, R.K. Atrial natriuretic factor receptor guanylate cyclase, ANF-RGC, transduces two independent signals, ANF and Ca(2+). Front Mol Neurosci 2014, 7, 17, doi:10.3389/fnmol.2014.00017.

125. Lobingier, B.T.; von Zastrow, M. When trafficking and signaling mix: How subcellular location shapes $G$ protein-coupled receptor activation of heterotrimeric $G$ proteins. Traffic 2019, 20, 130-136, doi:10.1111/tra.12634.

126. Kamp, M.E.; Liu, Y.; Kortholt, A. Function and Regulation of Heterotrimeric G Proteins during Chemotaxis. Int J Mol Sci 2016, 17, doi:10.3390/ijms17010090.

127. Schappi, J.M.; Krbanjevic, A.; Rasenick, M.M. Tubulin, actin and heterotrimeric G proteins: coordination of signaling and structure. Biochim Biophys Acta 2014, 1838, 674-681, doi:10.1016/j.bbamem.2013.08.026.

128. Ahmed, S.M.; Angers, S. Emerging non-canonical functions for heterotrimeric G proteins in cellular signaling. J Recept Signal Transduct Res 2013, 33, 177-183, doi:10.3109/10799893.2013.795972.

129. Wang, Y.; Li, Y.; Shi, G. The regulating function of heterotrimeric G proteins in the immune system. Arch Immunol Ther Exp (Warsz) 2013, 61, 309-319, doi:10.1007/s00005-013-0230-5.

130. Baltoumas, F.A.; Theodoropoulou, M.C.; Hamodrakas, S.J. Interactions of the alphasubunits of heterotrimeric G-proteins with GPCRs, effectors and RGS proteins: a critical review and analysis of interacting surfaces, conformational shifts, structural diversity and electrostatic potentials. J Struct Biol 2013, 182, 209-218, doi:10.1016/j.jsb.2013.03.004.

131. Tall, G.G. Ric-8 regulation of heterotrimeric G proteins. J Recept Signal Transduct Res 2013, 33, 139-143, doi:10.3109/10799893.2013.763828.

132. Naor, Z.; Huhtaniemi, I. Interactions of the GnRH receptor with heterotrimeric G proteins. Front Neuroendocrinol 2013, 34, 88-94, doi:10.1016/j.yfrne.2012.11.001.

133. Cooper, D.M.; Tabbasum, V.G. Adenylate cyclase-centred microdomains. Biochem J 2014, 462, 199-213, doi:10.1042/BJ20140560.

134. Jakobsen, E.; Lange, S.C.; Bak, L.K. Soluble adenylyl cyclase-mediated cAMP signaling and the putative role of PKA and EPAC in cerebral mitochondrial function. J Neurosci Res 2019, 97, 1018-1038, doi:10.1002/jnr.24477. 
135. Baldwin, T.A.; Dessauer, C.W. Function of Adenylyl Cyclase in Heart: the AKAP Connection. J Cardiovasc Dev Dis 2018, 5, doi:10.3390/jcdd5010002.

136. Jang, H.J.; Suh, P.G.; Lee, Y.J.; Shin, K.J.; Cocco, L.; Chae, Y.C. PLCgamma1: Potential arbitrator of cancer progression. Adv Biol Regul 2018, 67, 179-189, doi:10.1016/j.jbior.2017.11.003.

137. Nomikos, M.; Kashir, J.; Lai, F.A. The role and mechanism of action of sperm PLC-zeta in mammalian fertilisation. Biochem J 2017, 474, 3659-3673, doi:10.1042/BCJ20160521.

138. Nakamura, Y.; Fukami, K. Regulation and physiological functions of mammalian phospholipase C. J Biochem 2017, 161, 315-321, doi:10.1093/jb/mvw094.

139. Jho, E.H. Hippo signaling: Special issue of BMB Reports in 2018. BMB Rep 2018, 51, 105, doi:10.5483/bmbrep.2018.51.3.044.

140. Hubbard, S.R. Mechanistic Insights into Regulation of JAK2 Tyrosine Kinase. Front Endocrinol (Lausanne) 2017, 8, 361, doi:10.3389/fendo.2017.00361.

141. Bousoik, E.; Montazeri Aliabadi, H. "Do We Know Jack" About JAK? A Closer Look at JAK/STAT Signaling Pathway. Front Oncol 2018, 8, 287, doi:10.3389/fonc.2018.00287.

142. Hammaren, H.M.; Virtanen, A.T.; Raivola, J.; Silvennoinen, O. The regulation of JAKs in cytokine signaling and its breakdown in disease. Cytokine 2019, 118, 48-63, doi:10.1016/j.cyto.2018.03.041.

143. Satterthwaite, A.B. Bruton's Tyrosine Kinase, a Component of B Cell Signaling Pathways, Has Multiple Roles in the Pathogenesis of Lupus. Front Immunol 2017, 8, 1986, doi:10.3389/fimmu.2017.01986.

144. Blas-Rus, N.; Bustos-Moran, E.; Martin-Cofreces, N.B.; Sanchez-Madrid, F. Aurora-A shines on $\mathrm{T}$ cell activation through the regulation of Lck. Bioessays 2017, 39, doi:10.1002/bies.201600156.

145. Salah Ud-Din, A.I.M.; Roujeinikova, A. Methyl-accepting chemotaxis proteins: a core sensing element in prokaryotes and archaea. Cell Mol Life Sci 2017, 74, 3293-3303, doi:10.1007/s00018-017-2514-0.

146. Merilahti, J.A.M.; Elenius, K. Gamma-secretase-dependent signaling of receptor tyrosine kinases. Oncogene 2019, 38, 151-163, doi:10.1038/s41388-018-0465-z.

147. Van Opdenbosch, N.; Lamkanfi, M. Caspases in Cell Death, Inflammation, and Disease. Immunity 2019, 50, 1352-1364, doi:10.1016/j.immuni.2019.05.020.

148. Songane, M.; Khair, M.; Saleh, M. An updated view on the functions of caspases in inflammation and immunity. Semin Cell Dev Biol 2018, 82, 137-149, doi:10.1016/j.semcdb.2018.01.001.

149. Herr, A.B. Evolution of an allosteric "off switch" in apoptotic caspases. J Biol Chem 2018, 293, 5462-5463, doi:10.1074/jbc.H118.002379.

150. Varshney, P.; Yadav, V.; Saini, N. Lipid rafts in immune signalling: current progress and future perspective. Immunology 2016, 149, 13-24, doi:10.1111/imm.12617.

151. Resh, M.D. Covalent lipid modifications of proteins. Current biology : CB 2013, 23, R431R435, doi:10.1016/j.cub.2013.04.024.

152. Nair, A.; Chauhan, P.; Saha, B.; Kubatzky, K.F. Conceptual Evolution of Cell Signaling. Int J Mol Sci 2019, 20, doi:10.3390/ijms20133292. 
153. Tarrant, A.M. Endocrine-like Signaling in Cnidarians: Current Understanding and Implications for Ecophysiology. Integr Comp Biol 2005, 45, 201-214, doi:10.1093/icb/45.1.201.

154. Uchida, K.; Moriyama, S.; Chiba, H.; Shimotani, T.; Honda, K.; Miki, M.; Takahashi, A.; Sower, S.A.; Nozaki, M. Evolutionary origin of a functional gonadotropin in the pituitary of the most primitive vertebrate, hagfish. Proc Natl Acad Sci U S A 2010, 107, 15832-15837, doi:1002208107 [pii]

10.1073/pnas.1002208107.

155. Dufour, S.; Querat, B.; Tostivint, H.; Pasqualini, C.; Vaudry, H.; Rousseau, K. Origin and Evolution of the Neuroendocrine Control of Reproduction in Vertebrates, With Special Focus on Genome and Gene Duplications. Physiol Rev 2020, 100, 869-943, doi:10.1152/physrev.00009.2019.

156. Neuman, H.; Debelius, J.W.; Knight, R.; Koren, O. Microbial endocrinology: the interplay between the microbiota and the endocrine system. FEMS Microbiol Rev 2015, 39, 509-521, doi:10.1093/femsre/fuu010.

157. Lazar, V.; Ditu, L.M.; Pircalabioru, G.G.; Gheorghe, I.; Curutiu, C.; Holban, A.M.; Picu, A.; Petcu, L.; Chifiriuc, M.C. Aspects of Gut Microbiota and Immune System Interactions in Infectious Diseases, Immunopathology, and Cancer. Front Immunol 2018, 9, 1830, doi:10.3389/fimmu.2018.01830.

158. Cohen, L.J.; Esterhazy, D.; Kim, S.H.; Lemetre, C.; Aguilar, R.R.; Gordon, E.A.; Pickard, A.J.; Cross, J.R.; Emiliano, A.B.; Han, S.M., et al. Commensal bacteria make GPCR ligands that mimic human signalling molecules. Nature 2017, 549, 48-53, doi:10.1038/nature23874.

159. Kleino, A.; Myllymaki, H.; Kallio, J.; Vanha-aho, L.M.; Oksanen, K.; Ulvila, J.; Hultmark, D.; Valanne, S.; Ramet, M. Pirk is a negative regulator of the Drosophila Imd pathway. J Immunol 2008, 180, 5413-5422, doi:10.4049/jimmunol.180.8.5413.

160. Bosco-Drayon, V.; Poidevin, M.; Boneca, I.G.; Narbonne-Reveau, K.; Royet, J.; Charroux, B. Peptidoglycan sensing by the receptor PGRP-LE in the Drosophila gut induces immune responses to infectious bacteria and tolerance to microbiota. Cell Host Microbe 2012, 12, 153 165, doi:10.1016/j.chom.2012.06.002.

161. Bruning, J.; Chapp, A.; Kaurala, G.A.; Wang, R.; Techtmann, S.; Chen, Q.H. Gut Microbiota and Short Chain Fatty Acids: Influence on the Autonomic Nervous System. Neurosci Bull 2019, 10.1007/s12264-019-00410-8, doi:10.1007/s12264-019-00410-8.

162. Toral, M.; Robles-Vera, I.; de la Visitacion, N.; Romero, M.; Yang, T.; Sanchez, M.; GomezGuzman, M.; Jimenez, R.; Raizada, M.K.; Duarte, J. Critical Role of the Interaction Gut Microbiota - Sympathetic Nervous System in the Regulation of Blood Pressure. Front Physiol 2019, 10, 231, doi:10.3389/fphys.2019.00231.

163. Heiss, C.N.; Olofsson, L.E. The role of the gut microbiota in development, function and disorders of the central nervous system and the enteric nervous system. J Neuroendocrinol 2019, 31, e12684, doi:10.1111/jne.12684.

164. van de Wouw, M.; Stilling, R.M.; Peterson, V.L.; Ryan, F.J.; Hoban, A.E.; Shanahan, F.; Clarke, G.; Claesson, M.J.; Dinan, T.G.; Cryan, J.F., et al. Host Microbiota Regulates Central Nervous System Serotonin Receptor 2C Editing in Rodents. ACS Chem Neurosci 2019, 10, 3953-3960, doi:10.1021/acschemneuro.9b00414. 
165. Ma, Q.; Xing, C.; Long, W.; Wang, H.Y.; Liu, Q.; Wang, R.F. Impact of microbiota on central nervous system and neurological diseases: the gut-brain axis. J Neuroinflammation 2019, 16, 53, doi:10.1186/s12974-019-1434-3.

166. Whittaker, D.J.; Slowinski, S.P.; Greenberg, J.M.; Alian, O.; Winters, A.D.; Ahmad, M.M.; Burrell, M.J.E.; Soini, H.A.; Novotny, M.V.; Ketterson, E.D., et al. Experimental evidence that symbiotic bacteria produce chemical cues in a songbird. The Journal of Experimental Biology 2019, 222, jeb202978, doi:10.1242/jeb.202978.

167. Chen, Y.E.; Fischbach, M.A.; Belkaid, Y. Skin microbiota-host interactions. Nature 2018, 553, 427-436, doi:10.1038/nature25177.

168. Tang, D.; Wang, G.; Zhou, J.M. Receptor Kinases in Plant-Pathogen Interactions: More Than Pattern Recognition. Plant Cell 2017, 29, 618-637, doi:10.1105/tpc.16.00891.

169. Vincent, D.; Rafiqi, M.; Job, D. The Multiple Facets of Plant-Fungal Interactions Revealed Through Plant and Fungal Secretomics. Frontiers in Plant Science 2020, 10 , doi:10.3389/fpls.2019.01626.

170. Parniske, M. Arbuscular mycorrhiza: the mother of plant root endosymbioses. Nat Rev Microbiol 2008, 6, 763-775, doi:10.1038/nrmicro1987.

171. Markmann, K.; Giczey, G.; Parniske, M. Functional adaptation of a plant receptor-kinase paved the way for the evolution of intracellular root symbioses with bacteria. PLoS Biol 2008, 6, e68, doi:10.1371/journal.pbio.0060068.

172. Bedini, A.; Mercy, L.; Schneider, C.; Franken, P.; Lucic-Mercy, E. Unraveling the Initial Plant Hormone Signaling, Metabolic Mechanisms and Plant Defense Triggering the Endomycorrhizal Symbiosis Behavior. Front Plant Sci 2018, 9, 1800, doi:10.3389/fpls.2018.01800.

173. Wang, M.; Schafer, M.; Li, D.; Halitschke, R.; Dong, C.; McGale, E.; Paetz, C.; Song, Y.; Li, S.; Dong, J., et al. Blumenols as shoot markers of root symbiosis with arbuscular mycorrhizal fungi. Elife 2018, 7, doi:10.7554/eLife.37093.

174. Liu, C.-Y.; Zhang, F.; Zhang, D.-J.; Srivastava, A.K.; Wu, Q.-S.; Zou, Y.-N. Mycorrhiza stimulates root-hair growth and IAA synthesis and transport in trifoliate orange under drought stress. Scientific reports 2018, 8, 1978-1978, doi:10.1038/s41598-018-20456-4.

175. Schneider-Maunoury, L.; Deveau, A.; Moreno, M.; Todesco, F.; Belmondo, S.; Murat, C.; Courty, P.E.; Jakalski, M.; Selosse, M.A. Two ectomycorrhizal truffles, Tuber melanosporum and T. aestivum, endophytically colonize roots of non-ectomycorrhizal plants in natural environments. New Phytol 2019, 10.1111/nph.16321, doi:10.1111/nph.16321.

176. Deicke, M.; Mohr, J.F.; Roy, S.; Herzsprung, P.; Bellenger, J.P.; Wichard, T. Metallophore profiling of nitrogen-fixing Frankia spp. to understand metal management in the rhizosphere of actinorhizal plants. Metallomics 2019, 11, 810-821, doi:10.1039/c8mt00344k.

177. Desbrosses, G.J.; Stougaard, J. Root nodulation: a paradigm for how plant-microbe symbiosis influences host developmental pathways. Cell Host Microbe 2011, 10, 348-358, doi:10.1016/j.chom.2011.09.005.

178. Morieri, G.; Martinez, E.A.; Jarynowski, A.; Driguez, H.; Morris, R.; Oldroyd, G.E.; Downie, J.A. Host-specific Nod-factors associated with Medicago truncatula nodule infection differentially induce calcium influx and calcium spiking in root hairs. New Phytol 2013, 200, 656-662, doi:10.1111/nph.12475. 
179. Svistoonoff, S.; Hocher, V.; Gherbi, H. Actinorhizal root nodule symbioses: what is signalling telling on the origins of nodulation? Curr Opin Plant Biol 2014, 20, 11-18, doi:10.1016/j.pbi.2014.03.001.

180. Kawaharada, Y.; James, E.K.; Kelly, S.; Sandal, N.; Stougaard, J. The Ethylene Responsive Factor Required for Nodulation 1 (ERN1) Transcription Factor Is Required for InfectionThread Formation in Lotus japonicus. Mol Plant Microbe Interact 2017, 30, 194-204, doi:10.1094/MPMI-11-16-0237-R.

181. Sun, J.; Cardoza, V.; Mitchell, D.M.; Bright, L.; Oldroyd, G.; Harris, J.M. Crosstalk between jasmonic acid, ethylene and Nod factor signaling allows integration of diverse inputs for regulation of nodulation. Plant J 2006, 46, 961-970, doi:10.1111/j.1365-313X.2006.02751.x.

182. Oldroyd, G.E.; Engstrom, E.M.; Long, S.R. Ethylene inhibits the Nod factor signal transduction pathway of Medicago truncatula. Plant Cell 2001, 13, 1835-1849, doi:10.1105/tpc.010193.

183. Reid, D.; Liu, H.; Kelly, S.; Kawaharada, Y.; Mun, T.; Andersen, S.U.; Desbrosses, G.; Stougaard, J. Dynamics of Ethylene Production in Response to Compatible Nod Factor. Plant Physiol 2018, 176, 1764-1772, doi:10.1104/pp.17.01371.

184. McAdam, E.L.; Reid, J.B.; Foo, E. Gibberellins promote nodule organogenesis but inhibit the infection stages of nodulation. J Exp Bot 2018, 69, 2117-2130, doi:10.1093/jxb/ery046.

185. Fonouni-Farde, C.; Kisiala, A.; Brault, M.; Emery, R.J.N.; Diet, A.; Frugier, F. DELLA1Mediated Gibberellin Signaling Regulates Cytokinin-Dependent Symbiotic Nodulation. Plant Physiol 2017, 175, 1795-1806, doi:10.1104/pp.17.00919.

186. Griesmann, M.; Chang, Y.; Liu, X.; Song, Y.; Haberer, G.; Crook, M.B.; Billault-Penneteau, B.; Lauressergues, D.; Keller, J.; Imanishi, L., et al. Phylogenomics reveals multiple losses of nitrogen-fixing root nodule symbiosis. Science 2018, 361, doi:10.1126/science.aat1743.

187. Wu, Z.; Wang, M.; Yang, S.; Chen, S.; Chen, X.; Liu, C.; Wang, S.; Wang, H.; Zhang, B.; Liu, $\mathrm{H}$. , et al. A global coexpression network of soybean genes gives insights into the evolution of nodulation in nonlegumes and legumes. New Phytol 2019, 223, 2104-2119, doi:10.1111/nph.15845.

188. Nascimento, F.X.; Tavares, M.J.; Rossi, M.J.; Glick, B.R. The modulation of leguminous plant ethylene levels by symbiotic rhizobia played a role in the evolution of the nodulation process. Heliyon 2018, 4, e01068, doi:10.1016/j.heliyon.2018.e01068.

189. Kohlen, W.; Ng, J.L.P.; Deinum, E.E.; Mathesius, U. Auxin transport, metabolism, and signalling during nodule initiation: indeterminate and determinate nodules. J Exp Bot 2018, 69, 229-244, doi:10.1093/jxb/erx308.

190. Gough, C.; Cottret, L.; Lefebvre, B.; Bono, J.J. Evolutionary History of Plant LysM Receptor Proteins Related to Root Endosymbiosis. Front Plant Sci 2018, 9, 923, doi:10.3389/fpls.2018.00923.

191. Jiang, Y.; Wang, W.; Xie, Q.; Liu, N.; Liu, L.; Wang, D.; Zhang, X.; Yang, C.; Chen, X.; Tang, D., et al. Plants transfer lipids to sustain colonization by mutualistic mycorrhizal and parasitic fungi. Science 2017, 356, 1172-1175, doi:10.1126/science.aam9970.

192. Kalske, A.; Shiojiri, K.; Uesugi, A.; Sakata, Y.; Morrell, K.; Kessler, A. Insect Herbivory Selects for Volatile-Mediated Plant-Plant Communication. Curr Biol 2019, 29, 3128-3133 e3123, doi:10.1016/j.cub.2019.08.011. 
193. Glaum, P.; Kessler, A. Functional reduction in pollination through herbivore-induced pollinator limitation and its potential in mutualist communities. Nat Commun 2017, 8, 2031, doi:10.1038/s41467-017-02072-4.

194. Wang, L.; Einig, E.; Almeida-Trapp, M.; Albert, M.; Fliegmann, J.; Mithofer, A.; Kalbacher, H.; Felix, G. The systemin receptor SYR1 enhances resistance of tomato against herbivorous insects. Nat Plants 2018, 4, 152-156, doi:10.1038/s41477-018-0106-0.

195. Pashalidou, F.G.; Lambert, H.; Peybernes, T.; Mescher, M.C.; De Moraes, C.M. Bumble bees damage plant leaves and accelerate flower production when pollen is scarce. Science 2020, 368, 881-884, doi:10.1126/science.aay0496.

5. 